Prepared in cooperation with the New York State Department of Environmental Conservation

\title{
Groundwater Quality in Western New York, 2011
}

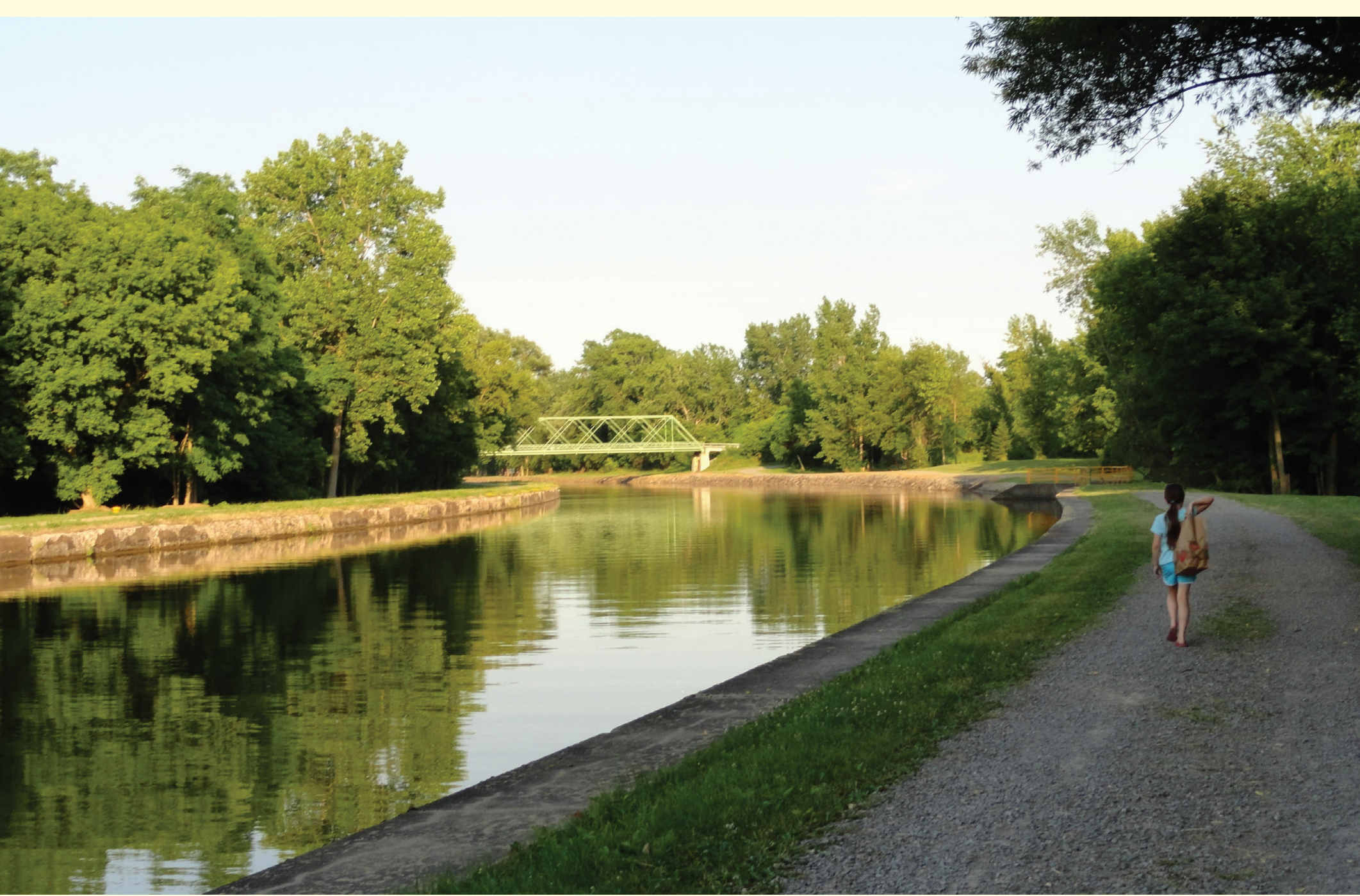

Open-File Report 2013-1095

U.S. Department of the Interior

U.S. Geological Survey 
Cover. Erie Canal, Holley, New York. Photo by Nancy Reddy, 2011. 


\section{Groundwater Quality in Western New York, 2011}

By James E. Reddy

Prepared in cooperation with the

New York State Department of Environmental Conservation

Open-File Report 2013-1095

U.S. Department of the Interior

U.S. Geological Survey 


\title{
U.S. Department of the Interior SALLY JEWELL, Secretary
}

\section{U.S. Geological Survey Suzette M. Kimball, Acting Director}

\author{
U.S. Geological Survey, Reston, Virginia: 2013
}

For more information on the USGS - the Federal source for science about the Earth, its natural and living resources, natural hazards, and the environment, visit http://www.usgs.gov or call 1-888-ASK-USGS.

For an overview of USGS information products, including maps, imagery, and publications, visit http://www.usgs.gov/pubprod

To order this and other USGS information products, visit http://store.usgs.gov

Any use of trade, firm, or product names is for descriptive purposes only and does not imply endorsement by the U.S. Government.

Although this information product, for the most part, is in the public domain, it also may contain copyrighted materials as noted in the text. Permission to reproduce copyrighted items must be secured from the copyright owner.

Suggested citation:

Reddy, J.E., 2013, Groundwater quality in western New York, 2011: U.S. Geological Survey

Open-File Report 2013-1095, 28 p., at http://pubs.usgs.gov/of/2013/1095/. 


\section{Contents}

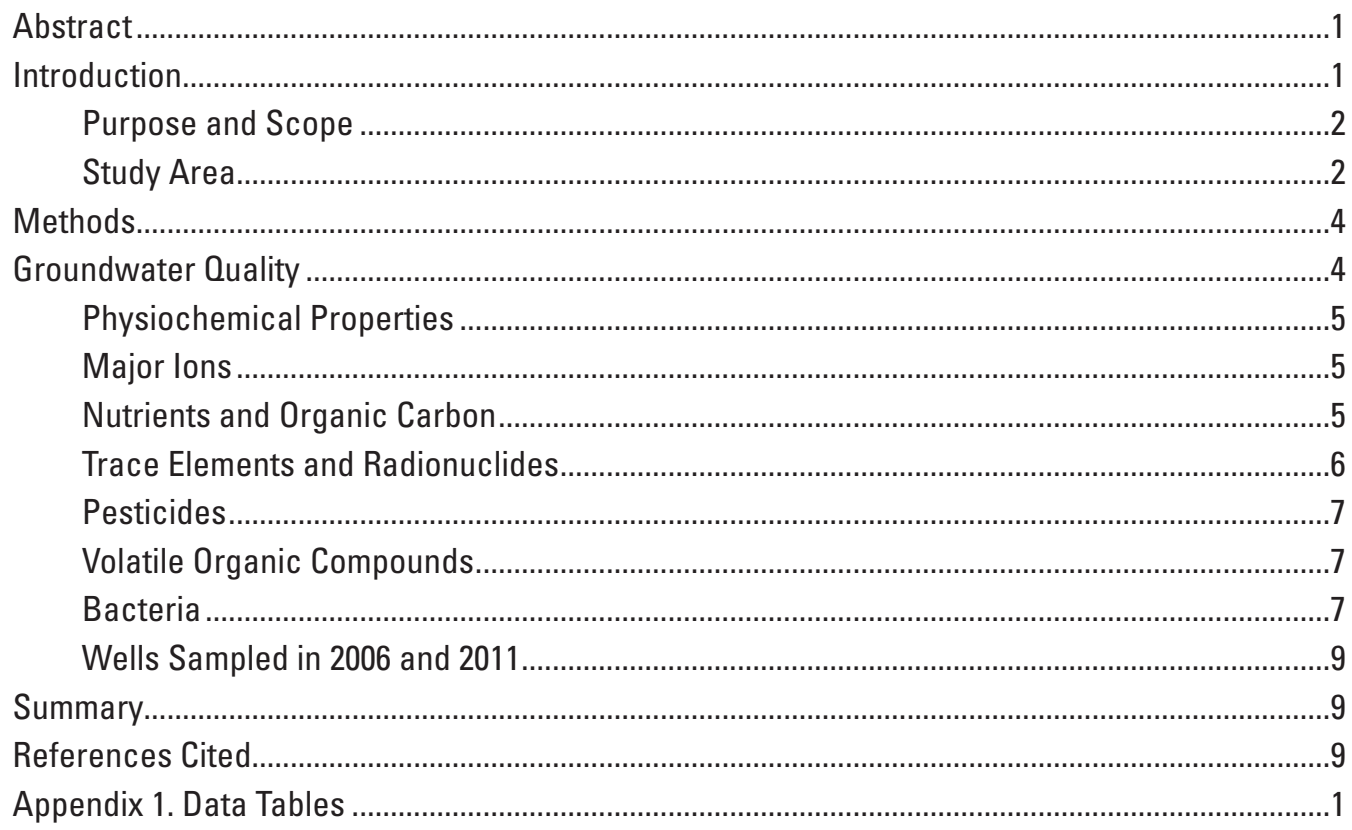

\section{Figure}

1. Maps showing $A$, pertinent geographic features of study area in western New York and locations of the 31 wells sampled in 2011 and B, general location and C, physiographic features of the study area. Well data are listed in table 1-1.....

\section{Tables}

1. Previous groundwater-quality studies and reports for New York State .2

2. Drinking-water standards and summary statistics for concentrations of major ions in groundwater samples from western New York, 2011

3. Drinking-water standards and summary statistics for concentrations of nutrients in groundwater samples from western New York, 2011.

4. Drinking-water standards and summary statistics for concentrations of trace elements and radionuclides in groundwater samples from western New York, 2011 ......8 


\section{Conversion Factors, Datum, and Abbreviations}

\begin{tabular}{|c|c|c|}
\hline Multiply & By & To obtain \\
\hline \multicolumn{3}{|c|}{ Length } \\
\hline inch (in.) & 2.54 & centimeter $(\mathrm{cm})$ \\
\hline foot $(\mathrm{ft})$ & 0.3048 & meter $(\mathrm{m})$ \\
\hline \multicolumn{3}{|c|}{ Area } \\
\hline square mile $\left(\mathrm{mi}^{2}\right)$ & 2.590 & square kilometer $\left(\mathrm{km}^{2}\right)$ \\
\hline \multicolumn{3}{|c|}{ Volume } \\
\hline million gallons (Mgal) & 3,785 & cubic meter $\left(\mathrm{m}^{3}\right)$ \\
\hline \multicolumn{3}{|c|}{ Flow rate } \\
\hline gallon per minute (gal/min) & 0.06309 & liter per second $(\mathrm{L} / \mathrm{s})$ \\
\hline gallon per day (gal/d) & 0.003785 & cubic meter per day $\left(\mathrm{m}^{3} / \mathrm{d}\right)$ \\
\hline million gallons per day (Mgal/d) & 0.04381 & cubic meter per second $\left(\mathrm{m}^{3} / \mathrm{s}\right)$ \\
\hline inch per year (in/yr) & 25.4 & millimeter per year (mm/yr) \\
\hline \multicolumn{3}{|c|}{ Radioactivity } \\
\hline picocurie per liter (pCi/L) & 0.037 & becquerel per liter $(\mathrm{Bq} / \mathrm{L})$ \\
\hline \multicolumn{3}{|c|}{ Temperature in degrees Celsius $\left({ }^{\circ} \mathrm{C}\right)$ may be converted to degrees Fahrenheit $\left({ }^{\circ} \mathrm{F}\right)$ as follows: } \\
\hline \multicolumn{3}{|l|}{${ }^{\circ} \mathrm{F}=\left(1.8 x^{\circ} \mathrm{C}\right)+32$} \\
\hline \multicolumn{3}{|c|}{ Temperature in degrees Fahrenheit $\left({ }^{\circ} \mathrm{F}\right)$ may be converted to degrees Celsius $\left({ }^{\circ} \mathrm{C}\right)$ as follows: } \\
\hline \multicolumn{3}{|c|}{${ }^{\circ} \mathrm{C}=\left({ }^{\circ} \mathrm{F}-32\right) / 1.8$} \\
\hline \multicolumn{3}{|c|}{$\begin{array}{l}\text { Vertical coordinate information is referenced to the National Geodetic Vertical Datum of } 1929 \\
\text { (NGVD 29). }\end{array}$} \\
\hline \multicolumn{3}{|c|}{ Horizontal coordinate information is referenced to the North American Datum of 1983 (NAD 83). } \\
\hline \multicolumn{3}{|c|}{$\begin{array}{l}\text { Specific conductance is given in microsiemens per centimeter at } 25 \text { degrees Celsius }(\mu \mathrm{S} / \mathrm{cm} \text { at } \\
\left.25^{\circ} \mathrm{C}\right) \text {. }\end{array}$} \\
\hline
\end{tabular}

\section{Abbreviations}

AMCL

alternative maximum contaminant level

CFCL USGS Chlorofluorocarbon Laboratory

$\mathrm{CFU} / \mathrm{mL}$ colony-forming units per milliliter

LRL laboratory reporting level

$\mathrm{MCL}$ maximum contaminant level

NWOL USGS National Water Quality Laboratory

NYSDEC New York State Department of Environmental Conservation

NYSDOH New York State Department of Health

Pt-Co units platinum-cobalt units 
OC

quality control

SDWS

secondary drinking-water standard

THM

trihalomethane

USEPA

U.S. Environmental Protection Agency

USGS

U.S. Geological Survey

VOC

volatile organic compound 
THIS PAGE INTENTIONALLY LEFT BLANK 


\title{
Groundwater Quality in Western New York, 2011
}

\author{
By James E. Reddy
}

\section{Abstract}

Water samples collected from 16 production wells and 15 private residential wells in western New York from July through November 2011 were analyzed to characterize the groundwater quality. Fifteen of the wells were finished in sand and gravel aquifers, and 16 were finished in bedrock aquifers. Six of the 31 wells were sampled in a previous western New York study, which was conducted in 2006. Water samples from the 2011 study were analyzed for 147 physiochemical properties and constituents that included major ions, nutrients, trace elements, radionuclides, pesticides, volatile organic compounds (VOCs), and indicator bacteria. Results of the waterquality analyses are presented in tabular form for individual wells, and summary statistics for specific constituents are presented by aquifer type. The results are compared with Federal and New York State drinking-water standards, which typically are identical. The results indicate that groundwater generally is of acceptable quality, although at 30 of the 31 wells sampled, at least one of the following constituents was detected at a concentration that exceeded current or proposed Federal or New York State drinking-water standards: $\mathrm{pH}$ (two samples), sodium (eight samples), sulfate (three samples), total dissolved solids (nine samples), aluminum (two samples), arsenic (one sample), iron (ten samples), manganese (twelve samples), radon-222 (sixteen samples), benzene (one sample), and total coliform bacteria (nine samples). Existing drinking-water standards for color, chloride, fluoride, nitrate, nitrite, antimony, barium, beryllium, cadmium, chromium, copper, lead, mercury, selenium, silver, thallium, zinc, gross alpha radioactivity, uranium, fecal coliform, Escherichia coli, and heterotrophic bacteria were not exceeded in any of the samples collected. None of the pesticides analyzed exceeded existing drinkingwater standards.

\section{Introduction}

Section 305(b) of the Federal Clean Water Act Amendments of 1977 requires that States monitor and report biennially on the chemical quality of surface water and groundwater within State boundaries (U.S. Environmental Protection Agency, 1997). In 2002, the U.S. Geological Survey (USGS) developed a program in cooperation with the New York State Department of Environmental Conservation (NYSDEC) to evaluate groundwater quality throughout the major river basins in New York on a rotating basis. The program parallels the NYSDEC Rotating Intensive Basin Study Program, which evaluates surface-water quality in 2 or 3 of the 14 major river basins in the State each year. The groundwater-quality program began in 2002 with a pilot study in the Mohawk River Basin and has continued throughout upstate New York since then (table 1). Sampling completed in 2008 represented the conclusion of a first round of groundwater-quality sampling throughout New York State (excluding Long Island, which is monitored through county programs). Groundwater-quality sampling was conducted in 2011 in the Mohawk River Basin and the Western Lake Ontario, Lake Erie-Niagara River, and Allegheny River Basins in western New York; these basins also were sampled in 2006 as part of the groundwater program. This report presents the results of the 2011 groundwater study in western New York.

Groundwater characteristics are affected by the geology and the land use of the area. Shallow wells that tap sand and gravel aquifers are susceptible to contamination by several kinds of compounds, including deicing chemicals, nutrients, pesticides, and volatile organic compounds (VOCs) from agricultural, industrial, residential areas, and upgradient highways. The movement of these contaminants to the water table through the soils and surficial sand and gravel can be relatively rapid. Bedrock wells that tap into sandstone and shale aquifers in rural upland areas generally are less susceptible to contamination from industrial and urban sources, which are mainly in the valleys; but bedrock wells in lowland areas underlain by carbonate bedrock (limestone and dolostone; Eckhardt and others, 2008), may be more vulnerable to contamination from surface runoff because infiltration rates and groundwater flow can be relatively rapid through bedrock solution features. Agricultural land upgradient of wells may be a potential source of contamination by fecal waste from livestock, fertilizers, and pesticides; lawns and residential septic systems also are a potential source of these contaminants. In addition to anthropogenic contaminants, the aquifers contain naturally derived constituents that may diminish water quality, such as arsenic, chloride, hydrogen sulfide, iron, manganese, methane, radon gas, sodium, and sulfate. 
Table 1. Previous groundwater-quality studies and reports for New York State.

\begin{tabular}{lcll}
\hline \multicolumn{1}{c}{ Study area } & Year & \multicolumn{1}{c}{ Report } & \multicolumn{1}{c}{ Reference } \\
\hline Mohawk River Basin & 2002 & Water-Data Report NY-02-1 & Butch and others, 2003 \\
\hline Chemung River Basin & 2003 & Open-File Report 2004-1329 & Hetcher-Aguila, 2005 \\
\hline Lake Champlain Basin & 2004 & Open-File Report 2006-1088 & Nystrom, 2006 \\
\hline Upper Susquehanna River Basin & $2004-5$ & Open-File Report 2006-1161 & Hetcher-Aguila and Eckhardt, 2006 \\
\hline Delaware River Basin & $2005-6$ & Open-File Report 2007-1098 & Nystrom, 2007b \\
\hline Genesee River Basin & $2005-6$ & Open-File Report 2007-1093 & Eckhardt and others, 2007 \\
\hline St. Lawrence River Basin & $2005-6$ & Open-File Report 2007-1066 & Nystrom, 2007a \\
\hline Mohawk River Basin & 2006 & Open-File Report 2008-1086 & Nystrom, 2008 \\
\hline Western New York & 2006 & Open-File Report 2008-1140 & Eckhardt and others, 2008 \\
\hline Central New York & 2007 & Open-File Report 2009-1257 & Eckhardt and others, 2009 \\
\hline Upper Hudson River Basin & 2007 & Open-File Report 2009-1240 & Nystrom, 2009 \\
\hline Eastern Lake Ontario Basin & 2008 & Open-File Report 2011-1074 & Risen and Reddy, 2011a \\
\hline Chemung River Basin & 2008 & Open-File Report 2011-1112 & Risen and Reddy, 2011b \\
\hline Lower Hudson River Basin & 2008 & Open-File Report 2010-1197 & Nystrom, 2010 \\
\hline Lake Champlain Basin & 2009 & Open-File Report 2011-1180 & Nystrom, 2011 \\
\hline Upper Susquehanna River Basin & 2009 & Open-File Report 2012-1045 & Reddy and Risen, 2012 \\
\hline Delaware River Basin & 2010 & Open-File Report 2011-1320 & Nystrom, 2012 \\
\hline St. Lawrence River Basin & 2010 & Open-File Report 2011-1320 & Nystrom, 2012 \\
\hline Genesee River Basin & 2010 & Open-File Report 2012-1135 & Reddy, 2012 \\
\hline Mohawk River Basin & 2011 & Open-File Report 2013-1021 & Nystrom and Scott, 2013 \\
\hline
\end{tabular}

\section{Purpose and Scope}

This report supplements the water-quality study completed in 2006 for western New York (Eckhardt and others, 2008) by resampling 6 of the production wells from that study (AG 265, E1903, E1904, GS 216, OL 19, and WO 351) and provides analytical results for 25 new wells (fig. 1). This report briefly describes the study area and the sampling methods and presents results of the water-quality analyses for the 31 wells sampled in 2011. Summary statistics of the number of samples exceeding Federal or State drinking-water standards and the minimum, median, and maximum concentrations of selected analytes in sand and gravel and bedrock aquifers are provided in tables 2 through 4; information on the sampled wells and detailed analytical results for all analytes are provided in the appendix (tables 1-1 through 1-9).

\section{Study Area}

The 5,340-square mile $\left(\mathrm{mi}^{2}\right)$ study area includes all or parts of the nine westernmost counties of New York (fig. 1). It encompasses parts of the Lake Erie and Niagara River Basin, the western Lake Ontario Basin (between the Niagara River and Genesee River Basins), and the Allegheny River Basin (fig. 1). The parts of these drainage basins that lie outside
New York's boundaries were not included in this study. A complete description of the study area is included in Eckhardt and others (2008).

The central, southern, and eastern parts of the study area lie within the Appalachian Plateau physiographic province (fig. 1), the northern part lies in the Lake Ontario Lowlands province, and the western part lies in the Lake Erie Lowlands province. Forest and pasture dominate the uplands and narrow valleys of the southern and eastern parts of the study area; cultivation of row crops, apples, and grapes is common in the Lake Erie and Lake Ontario lowlands; and row-crop, foragecrop, and dairy farming are concentrated in a band of fertile soils between Buffalo and Rochester. The Buffalo and Niagara Falls metropolitan area lies near the outlet of Lake Erie and extends northward along the Niagara River. The study area contains several small lakes, such as Chautauqua Lake, and is crossed by the New York State Barge (Erie) Canal, which traverses the State from Albany to Buffalo.

During deglaciation of the region, sand and gravel were deposited by meltwater streams, and clay, silt, and fine sand were deposited in proglacial lakes. The glaciofluvial and glaciolacustrine deposits within the study area are described in detail by Coates (1966) and Randall (2001). The most productive aquifers within the study area are the glaciofluvial deposits of sand and gravel in the valleys. Bedrock aquifers 

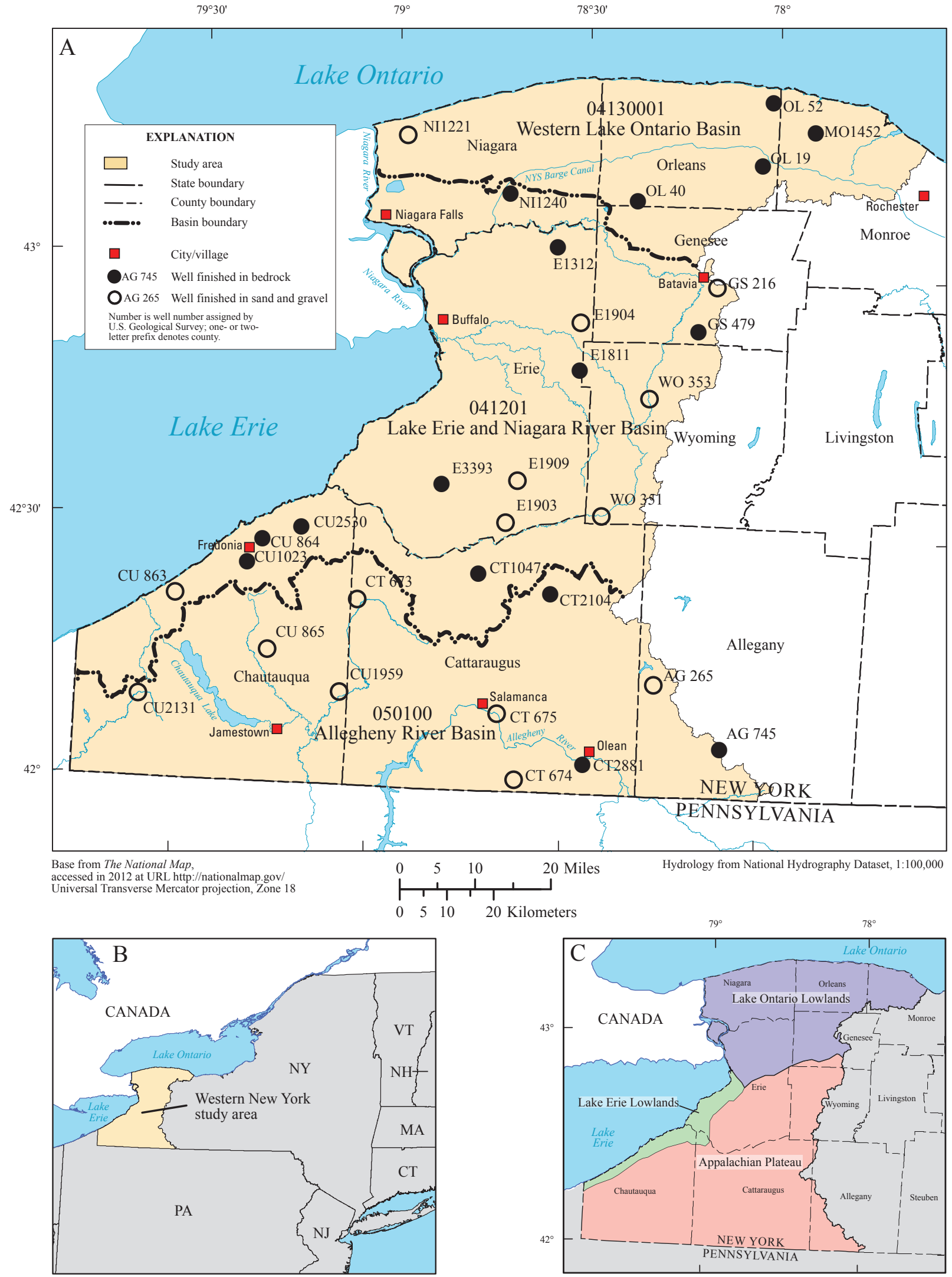

Figure 1. A, pertinent geographic features of study area in western New York and locations of the 31 wells sampled in 2011 and $B$, general location and $C$, physiographic features of the study area. Well data are listed in table 1-1. 
typically are used for water supply in upland areas where sand and gravel aquifers generally are absent. The bedrock aquifers throughout most of the study area are relatively flat-lying interbedded sedimentary units of shale, siltstone, sandstone, limestone, and dolostone of Silurian and Devonian age (Fisher and others, 1970).

\section{Methods}

A total of 31 wells (table 1-1) were selected for sample collection as described by Eckhardt and others (2008) - 15 were finished in sand and gravel aquifers and 16 were finished in bedrock aquifers. Of the 15 wells that tap into sand and gravel aquifers, 13 are production wells and 2 are private residential wells. Of the 16 bedrock wells, 3 are production wells and 13 are private residential wells. Samples were collected from July through November 2011. The water samples were analyzed for 147 physiochemical properties and constituents that included major ions, nutrients, trace elements, radionuclides, pesticides, VOCs, and indicator bacteria.

Wells were selected to provide adequate spatial coverage of the study area. The study did not target specific municipalities, industries, or agricultural practices. The private residential wells were selected on the basis of information from the NYSDEC Water Well Program, which began in 2000. Production wells were selected using information from the NYSDEC Water Well Program and the New York State Department of Health (NYSDOH) Drinking Water Protection Program.

Most of the wells that are finished in sand and gravel were in the valleys and ranged from 36 to 177 feet (ft) deep (table 1-1). The wells that are finished in bedrock were generally in the uplands and ranged from 25 to $218 \mathrm{ft}$ deep; all the bedrock wells were finished in sedimentary units of shale, siltstone, sandstone, limestone, dolostone, and evaporites (table 1-1).

In addition to the 31 groundwater samples, three quality control (QC) samples - two field blanks and one concurrent replicate sample - were collected. The QC blank samples contained no constituents in concentrations greater than the laboratory reporting levels (LRLs) except silica, boron, and iron (unfiltered), which were detected at trace concentrations. This indicates that little to no contamination occurred through the sampling or analytical procedures. The variability between the replicate sample and the corresponding environmental sample was greatest for unfiltered trace elements. The LRL is generally equal to twice the annual determined long-term method detection level (LT-MDL). The LRL controls false negative error. The probability of falsely reporting a nondetection result for a sample that contained an analyte at a concentration equal to or greater than the LRL is predicted to be less than or equal to 1 percent. The value of the LRL is indicated as less than $(<)$ for samples in which the analyte was not detected. The USGS National Water Quality Laboratory (NWQL) in Denver, Colorado, collects quality-control data from selected analytical methods on a continuing basis to determine LT-MDLs and to establish LRLs. These values are reevaluated annually based on the most current quality-control data, and, therefore, may change (Childress and others, 1999).

Three pesticides were detected in the replicate sample; deethylatrazine (CIAT) and prometon at estimated concentrations of 0.001 micrograms per liter $(\mu \mathrm{g} / \mathrm{L})$, and atrazine at an estimated concentration of $0.003 \mu \mathrm{g} / \mathrm{L}$. The concentrations of these three pesticides were identical in the corresponding environmental sample except for atrazine, which was detected at an estimated concentration of $0.002 \mu \mathrm{g} / \mathrm{L}$ in the environmental sample.

Groundwater-sample collection and processing followed standard USGS procedures as documented in the National Field Manual for the Collection of Water-Quality Data (U.S. Geological Survey, variously dated). All samples except those for radionuclide analyses were chilled to 4 degrees Celsius $\left({ }^{\circ} \mathrm{C}\right)$ or less and were kept chilled until delivery to the analyzing laboratory. The samples were delivered directly or shipped by overnight delivery to four laboratories: (1) the NWQL for analysis of inorganic major ions, nutrients, total organic carbon, inorganic trace elements, radon-222, pesticides and pesticide degradates, and VOCs; (2) the USGS Chlorofluorocarbon Laboratory (CFCL) in Reston, Virginia, for select dissolved gases; (3) Eberline Services in Richmond, California, for gross-alpha and gross-beta radioactivities; and (4) a NYSDOH-certified laboratory in Depew, New York, for bacterial analysis. Physiochemical properties, such as water temperature, $\mathrm{pH}$, dissolved oxygen concentration, and specific conductance, were measured at the sampling site.

\section{Groundwater Quality}

Samples from 31 wells were analyzed for 147 physiochemical properties and constituents. Many of these (65) were not detected above the LRLs in any sample (table 1-2). Results for the remaining 82 physiochemical properties and constituents that were detected are presented in tables 1-3 through 1-9. The categories of physiochemical properties and the concentrations of constituents are presented in appendix 1 as follows: physiochemical properties in table 1-3, major ions in table 1-4, nutrients and total organic carbon in table $1-5$, trace elements and radionuclides in table $1-6$, pesticides in table $1-7$, VOCs in table $1-8$, and bacterial water-quality indicators in table 1-9. Some concentrations were reported as estimated when the detected value was less than the established LRL or when recovery of a compound has been documented to be highly variable (Childress and others, 1999).

Analytical results for selected constituents were compared with Federal and New York State drinking-water standards, which are typically identical. The standards include maximum contaminant levels (MCLs) and secondary drinking-water standards (SDWS) established by the U.S. Environmental Protection Agency (USEPA; U.S. Environmental 
Protection Agency, 1999, 2002, 2009) and the NYSDOH (New York State Department of Health, 2011). The MCLs are enforceable standards that specify the highest level of a contaminant that is allowed in public-water drinking supplies; they are not enforceable for private residential wells but are presented here as a guideline for evaluation of the water-quality results. The SDWS are nonenforceable guidelines and are based on cosmetic and aesthetic criteria, such as taste, odor, or staining of plumbing fixtures.

The quality of the sampled groundwater generally was acceptable, although in samples from 30 of the 31 wells, the concentration of at least one constituent exceeded recommended MCLs or SDWSs set by the USEPA or the NYSDOH. Exceedances generally involved minerals and chemical elements that occur from natural interactions of water and rock (aluminum, arsenic, iron, manganese, radon-222, sodium, and sulfate) but also included benzene, which is a VOC, and total coliform bacteria contamination.

\section{Physiochemical Properties}

The color values for all samples (table 1-3) were less than 1 platinum-cobalt (Pt-Co) unit (the LRL) except for one sample from a bedrock well with a value of $2 \mathrm{Pt}-\mathrm{Co}$ units. The NYSDOH MCL and USEPA SDWS of $15 \mathrm{Pt}$-Co units were not exceeded in any sample. The $\mathrm{pH}$ of the samples ranged from 6.0 to 8.7; the median was 7.6 for sand and gravel wells and 7.4 for bedrock wells. Two of the 31 wells had $\mathrm{pH}$ values outside the accepted USEPA SDWS range of 6.5 to 8.5: a $\mathrm{pH}$ of 6.0 was detected at a sand and gravel well, and a $\mathrm{pH}$ of 8.7 was detected at a bedrock well (U.S. Environmental Protection Agency, 2009). The specific conductance of the samples ranged from 138 to 2,450 microsiemens per centimeter $(\mu \mathrm{S} / \mathrm{cm})$ at $25^{\circ} \mathrm{C}$; the median was $454 \mu \mathrm{S} / \mathrm{cm}$ at $25^{\circ} \mathrm{C}$ for sand and gravel wells and $592 \mu \mathrm{S} / \mathrm{cm}$ at $25^{\circ} \mathrm{C}$ for bedrock wells. The temperature of the water ranged from 8.7 to $19.3{ }^{\circ} \mathrm{C}$; the median was $12.1{ }^{\circ} \mathrm{C}$ for sand and gravel wells and $12.8^{\circ} \mathrm{C}$ for bedrock wells.

Dissolved-oxygen concentrations ranged from 0.2 to 8.1 milligrams per liter $(\mathrm{mg} / \mathrm{L})$; the median was $3.1 \mathrm{mg} / \mathrm{L}$ for sand and gravel wells and $0.5 \mathrm{mg} / \mathrm{L}$ for bedrock wells. Methane concentrations ranged from less than 0.0005 (the LRL) to $29.5 \mathrm{mg} / \mathrm{L}$; the median was $0.003 \mathrm{mg} / \mathrm{L}$ for sand and gravel wells and $0.024 \mathrm{mg} / \mathrm{L}$ for bedrock wells. The odor of hydrogen sulfide gas, which may occur in the absence of oxygen, was noted by field personnel in water from five sand and gravel wells and seven bedrock wells.

\section{Major lons}

The cations that were detected in the greatest concentrations were calcium and sodium (tables 2,1-4). Calcium concentrations ranged from 2.26 to $485 \mathrm{mg} / \mathrm{L}$; the median was $54.2 \mathrm{mg} / \mathrm{L}$ for sand and gravel wells and $71.7 \mathrm{mg} / \mathrm{L}$ for bedrock wells. Magnesium concentrations ranged from
0.51 to $65.6 \mathrm{mg} / \mathrm{L}$; the median was $11.0 \mathrm{mg} / \mathrm{L}$ for sand and gravel wells and $14.6 \mathrm{mg} / \mathrm{L}$ for bedrock wells. Potassium concentrations ranged from 0.64 to $13.5 \mathrm{mg} / \mathrm{L}$; the median was $1.58 \mathrm{mg} / \mathrm{L}$ for sand and gravel wells and $1.80 \mathrm{mg} / \mathrm{L}$ for bedrock wells. Sodium concentrations ranged from 2.15 to $144 \mathrm{mg} / \mathrm{L}$; the median was $20.3 \mathrm{mg} / \mathrm{L}$ for sand and gravel wells and $21.6 \mathrm{mg} / \mathrm{L}$ for bedrock wells. The USEPA nonregulatory drinking-water advisory threshold for taste recommends that sodium concentrations in drinking water not exceed the range of 30 to $60 \mathrm{mg} / \mathrm{L}$ (U.S. Environmental Protection Agency, 2002, 2009). The concentration of sodium in samples from four sand and gravel wells and five bedrock wells exceeded the upper limit of the USEPA threshold.

The anions that were detected in the greatest concentration were bicarbonate and sulfate (tables 2,1-4). Bicarbonate concentrations ranged from 45 to $388 \mathrm{mg} / \mathrm{L}$; the median was $207 \mathrm{mg} / \mathrm{L}$ for sand and gravel wells and $280 \mathrm{mg} / \mathrm{L}$ for bedrock wells. Chloride concentrations ranged from 1.64 to $180 \mathrm{mg} / \mathrm{L}$; the median was $41.1 \mathrm{mg} / \mathrm{L}$ for sand and gravel wells and $27.1 \mathrm{mg} / \mathrm{L}$ for bedrock wells. Fluoride concentrations ranged from less than 0.04 (the LRL) to $1.17 \mathrm{mg} / \mathrm{L}$; the median was $0.07 \mathrm{mg} / \mathrm{L}$ for sand and gravel wells and $0.18 \mathrm{mg} / \mathrm{L}$ for bedrock wells. Silica concentrations ranged from 5.92 to $19.4 \mathrm{mg} / \mathrm{L}$; the median was $9.39 \mathrm{mg} / \mathrm{L}$ for sand and gravel wells and $12.9 \mathrm{mg} / \mathrm{L}$ for bedrock wells. Sulfate concentrations ranged from less than $0.09 \mathrm{mg} / \mathrm{L}$ (the $\mathrm{LRL}$ ) to $1,240 \mathrm{mg} / \mathrm{L}$; the median was $17.2 \mathrm{mg} / \mathrm{L}$ for sand and gravel wells and $30.3 \mathrm{mg} / \mathrm{L}$ for bedrock wells. The NYSDOH MCL and USEPA SDWS of $250 \mathrm{mg} / \mathrm{L}$ for sulfate were exceeded in samples from three bedrock wells.

Calcium and magnesium contribute to water hardness. Water hardness in the basin (tables 2,1-4) ranged from 7.75 to $1,400 \mathrm{mg} / \mathrm{L}$ (as $\mathrm{CaCO}_{3}$ ); the median was $171 \mathrm{mg} / \mathrm{L}$ for sand and gravel wells and $252 \mathrm{mg} / \mathrm{L}$ for bedrock wells. Seven of the samples were soft to moderately hard (equal to or less than $120 \mathrm{mg} / \mathrm{L}$ as $\mathrm{CaCO}_{3}$ ) and 24 wells yielded water that was hard to very hard (greater than $120 \mathrm{mg} / \mathrm{L}$ as $\left.\mathrm{CaCO}_{3}\right)(\mathrm{Hem}$, 1985). Wells finished in bedrock were slightly more alkaline (median of $229 \mathrm{mg} / \mathrm{L}$ as $\mathrm{CaCO}_{3}$ ) than those finished in sand and gravel (median of $170 \mathrm{mg} / \mathrm{L}$ as $\mathrm{CaCO}_{3}$ ). Concentrations of dissolved solids ranged from 68 to $2,240 \mathrm{mg} / \mathrm{L}$, with a median of $251 \mathrm{mg} / \mathrm{L}$ for sand and gravel wells and $340 \mathrm{mg} / \mathrm{L}$ for bedrock wells. The USEPA SDWS of $500 \mathrm{mg} / \mathrm{L}$ for dissolved solids was exceeded in four sand and gravel wells and five bedrock wells.

\section{Nutrients and Organic Carbon}

Nitrate was the predominant nutrient in the groundwater samples (tables 3, 1-5). Concentrations of ammonia ranged from less than 0.010 (the $\mathrm{LRL}$ ) to $1.01 \mathrm{mg} / \mathrm{L}$ as nitrogen $(\mathrm{N})$; the median concentration was $0.011 \mathrm{mg} / \mathrm{L}$ as $\mathrm{N}$ in samples from sand and gravel wells and $0.078 \mathrm{mg} / \mathrm{L}$ as $\mathrm{N}$ in samples from bedrock wells. Concentrations of nitrate plus nitrite ranged from less than 0.02 (the $\mathrm{LRL}$ ) to $2.74 \mathrm{mg} / \mathrm{L}$ as N; the 
Table 2. Drinking-water standards and summary statistics for concentrations of major ions in groundwater samples from western New York, 2011.

[All concentrations in milligrams per liter in filtered water. $\mathrm{CaCO}_{3}$, calcium carbonate; No., number; --, not applicable; $<$, less than; ${ }^{\circ} \mathrm{C}$, degrees Celsius]

\begin{tabular}{|c|c|c|c|c|c|c|c|c|c|}
\hline & \multirow{2}{*}{ Constituent } & \multirow{2}{*}{$\begin{array}{l}\text { Drinking- } \\
\text { water } \\
\text { standard }\end{array}$} & \multirow{2}{*}{$\begin{array}{c}\text { No. of } \\
\text { samples } \\
\text { exceeding } \\
\text { standard }\end{array}$} & \multicolumn{3}{|c|}{ Sand and gravel (15 samples) } & \multicolumn{3}{|c|}{ Bedrock (16 samples) } \\
\hline & & & & Minimum & Median & Maximum & Minimum & Median & Maximum \\
\hline \multirow[t]{4}{*}{ Cations } & Calcium & -- & -- & 19.1 & 54.2 & 142 & 2.26 & 71.7 & 485 \\
\hline & Magnesium & -- & -- & 4.58 & 11.0 & 30.0 & .51 & 14.6 & 65.6 \\
\hline & Potassium & -- & -- & .64 & 1.58 & 10.2 & .70 & 1.80 & 13.5 \\
\hline & Sodium & ${ }^{1} 60$ & 9 & 2.15 & 20.3 & 95.9 & 3.64 & 21.6 & 144 \\
\hline \multirow[t]{5}{*}{ Anions } & Bicarbonate & -- & -- & 45 & 207 & 360 & 48 & 280 & 388 \\
\hline & Chloride & 2,3250 & 0 & 4.85 & 41.1 & 180 & 1.64 & 27.1 & 177 \\
\hline & Fluoride & $\begin{array}{r}{ }^{4} 4.0 \\
22.0 \\
{ }^{3} 2.2\end{array}$ & 0 & $<.04$ & .07 & .46 & .04 & .18 & 1.17 \\
\hline & Silica & -- & -- & 5.92 & 9.39 & 15.6 & 6.06 & 12.9 & 19.4 \\
\hline & Sulfate & 2,3250 & 3 & 7.07 & 17.2 & 127 & $<.09$ & 30.3 & 1,240 \\
\hline \multicolumn{2}{|c|}{ Hardness as $\mathrm{CaCO}_{3}$} & -- & -- & 69 & 171 & 452 & 7.75 & 252 & 1,400 \\
\hline \multicolumn{2}{|c|}{ Alkalinity as $\mathrm{CaCO}_{3}$} & -- & -- & 37 & 170 & 295 & 39 & 229 & 318 \\
\hline \multicolumn{2}{|c|}{ Dissolved solids, dried at $180^{\circ} \mathrm{C}$} & 3500 & 9 & 141 & 251 & 714 & 68 & 340 & 2,240 \\
\hline
\end{tabular}

median concentration was $0.62 \mathrm{mg} / \mathrm{L}$ as $\mathrm{N}$ in samples from sand and gravel wells and $0.03 \mathrm{mg} / \mathrm{L}$ as $\mathrm{N}$ in samples from bedrock wells. The concentration of nitrate plus nitrite did not exceed the USEPA and NYSDOH MCLs of $10 \mathrm{mg} / \mathrm{L}$ as $\mathrm{N}$ in any sample. Nitrite was detected in five samples; the highest concentration was $0.010 \mathrm{mg} / \mathrm{L}$ as N. The concentration of nitrite did not exceed the MCL ( $1 \mathrm{mg} / \mathrm{L}$ as $\mathrm{N})$ in any sample. Orthophosphate concentrations ranged from less than 0.004 (the LRL) to $0.035 \mathrm{mg} / \mathrm{L}$ as phosphorus (P). Organic carbon was detected in 14 of the 31 samples; the maximum concentration was $1.9 \mathrm{mg} / \mathrm{L}$.

\section{Trace Elements and Radionuclides}

The trace elements detected in the greatest concentrations (more than $100 \mu \mathrm{g} / \mathrm{L}$ ) were aluminum, barium, boron, copper, iron, lithium, manganese, and strontium (tables 4, 1-6). The largest detected concentration of a trace element, 19,900 $\mu \mathrm{g} / \mathrm{L}$, was of strontium in a sample from a bedrock well. The concentration of aluminum in one sample from a bedrock well, $948 \mu \mathrm{g} / \mathrm{L}$, exceeded the upper limit of the USEPA SDWS of $200 \mu \mathrm{g} / \mathrm{L}$. The lower limit of the USEPA SDWS for aluminum $(50 \mu \mathrm{g} / \mathrm{L})$ was exceeded in one sample from a second bedrock well with a concentration of $51 \mu \mathrm{g} / \mathrm{L}$. The concentration of arsenic in one sample from a sand and gravel well, $14.1 \mu \mathrm{g} / \mathrm{L}$, exceeded the USEPA and NYSDOH MCLs of $10 \mu \mathrm{g} / \mathrm{L}$. The concentration of iron in 9 filtered samples and 10 unfiltered samples exceeded the USEPA SDWS and the NYSDOH MCL of $300 \mu \mathrm{g} / \mathrm{L}$. The concentration of manganese in 12 filtered samples and 12 unfiltered samples exceeded the USEPA SDWS of $50 \mu \mathrm{g} / \mathrm{L}$; the NYSDOH MCL of $300 \mu \mathrm{g} / \mathrm{L}$ was exceeded in one filtered sample and one unfiltered sample. Drinking-water standards for antimony, barium, beryllium, cadmium, chromium, copper, lead, mercury, selenium, silver, thallium, uranium, and zinc were not exceeded; additionally, mercury was not detected in any sample (table 1-2).

Three measures of radioactivity were employed (tables 4, 1-6). Gross-alpha activity ranged from less than 0.5 to 3.8 picocuries per liter $(\mathrm{pCi} / \mathrm{L})$. The median activity was less than $1.1 \mathrm{pCi} / \mathrm{L}$ in samples from sand and gravel wells and $0.9 \mathrm{pCi} / \mathrm{L}$ in samples from bedrock wells. The gross-alpha activity did not exceed the USEPA and NYSDOH MCLs of $15 \mathrm{pCi} / \mathrm{L}$ in any sample. Gross-beta activity ranged from less than 0.63 to $15.0 \mathrm{pCi} / \mathrm{L}$. The median activity was $1.6 \mathrm{pCi} / \mathrm{L}$ in samples from sand and gravel wells and $2.0 \mathrm{pCi} / \mathrm{L}$ in samples from bedrock wells. The USEPA and NYSDOH MCLs for gross beta are expressed as a dose of 4 millirems per year; therefore, it cannot be evaluated whether any of the samples 
Table 3. Drinking-water standards and summary statistics for concentrations of nutrients in groundwater samples from western New York, 2011.

[All concentrations in milligrams per liter in filtered water except as noted. N, nitrogen; No., number; P, phosphorus; --, not applicable; <, less than]

\begin{tabular}{|c|c|c|c|c|c|c|c|c|}
\hline \multirow[b]{2}{*}{ Constituent } & \multirow{2}{*}{$\begin{array}{l}\text { Drinking- } \\
\text { water } \\
\text { standard }\end{array}$} & \multirow{2}{*}{$\begin{array}{c}\text { No. of } \\
\text { samples } \\
\text { exceeding } \\
\text { standard }\end{array}$} & \multicolumn{3}{|c|}{ Sand and gravel (15 samples) } & \multicolumn{3}{|c|}{ Bedrock (16 samples) } \\
\hline & & & Minimum & Median & Maximum & Minimum & Median & Maximum \\
\hline Ammonia plus organic $\mathrm{N}$, as $\mathrm{N}$ & -- & -- & $<.05$ & .08 & .28 & $<.05$ & .16 & 1.2 \\
\hline Ammonia, as $\mathrm{N}$ & -- & -- & $<.010$ & .011 & .251 & $<.010$ & .078 & 1.01 \\
\hline Nitrate plus nitrite, as $\mathrm{N}$ & 1,210 & 0 & $<.02$ & .62 & 1.96 & $<.02$ & .03 & 2.74 \\
\hline Nitrite, as $\mathrm{N}$ & 1,21 & 0 & $<.001$ & $<.001$ & .001 & $<.001$ & $<.001$ & .010 \\
\hline Orthophosphate, as P & -- & -- & $<.004$ & .009 & .035 & $<.004$ & .006 & .031 \\
\hline Total organic carbon, unfiltered & -- & -- & $<.3$ & $<.5$ & 1.6 & $<.3$ & .9 & 1.9 \\
\hline
\end{tabular}

${ }^{1}$ U.S. Environmental Protection Agency maximum contaminant level.

${ }^{2}$ New York State Department of Health maximum contaminant level.

exceeded the MCL. Radon-222 was detected in every sample, and activity ranged from 56 to $1,880 \mathrm{pCi} / \mathrm{L}$. The median activity was $510 \mathrm{pCi} / \mathrm{L}$ in samples from sand and gravel wells and $290 \mathrm{pCi} / \mathrm{L}$ in samples from bedrock wells. Radon currently is not regulated in drinking water; however, the USEPA proposed MCL of $300 \mathrm{pCi} / \mathrm{L}$ for radon-222 in drinking water was exceeded in 16 samples, but the USEPA proposed alternate maximum contaminant level (AMCL) of $4,000 \mathrm{pCi} / \mathrm{L}$ was not exceeded. The AMCL is the proposed allowable activity of radon in raw-water samples where the State has implemented mitigation programs to address the health risks of radon in indoor air. The proposed MCL and AMCL for radon are under review and have not been adopted (Krieger and Whitaker, 1980; U.S. Environmental Protection Agency, 1999, 2009).

\section{Pesticides}

Nine pesticides (eight herbicides and one herbicide degradate) were detected in samples from 12 wells (table 1-7). The pesticides were detected in samples from eight sand and gravel wells and four bedrock wells. All pesticide concentrations were in hundredths or thousandths of micrograms per liter. There were a total of 26 pesticide detections; 14 of those have estimated concentrations and 3 detections could not be quantified. The herbicide atrazine was detected in five samples; one of those samples, from a bedrock well, had the highest concentration $(0.032 \mu \mathrm{g} / \mathrm{L})$ of all pesticide detections. The atrazine degradate CIAT is the constituent detected most frequently (10 samples). The sample from one bedrock well (a production well in an agricultural setting) had the most (seven) pesticide detections. None of the pesticides analyzed contained concentrations that exceeded established drinking-water standards.

\section{Volatile Organic Compounds}

Thirteen VOCs were detected in samples from four sand and gravel wells and seven bedrock wells (table 1-8). The concentration of benzene in a sample from one private residential bedrock well $(56.1 \mu \mathrm{g} / \mathrm{L})$ exceeded the USEPA and NYSDOH MCLs of $5 \mu \mathrm{g} / \mathrm{L}$. Benzene was detected in two other bedrock wells at concentrations of $0.1 \mu \mathrm{g} / \mathrm{L}$ and $1.6 \mu \mathrm{g} / \mathrm{L}$.

Bromodichloromethane, tribromomethane, trichloromethane, and dibromochloromethane were detected in samples from two sand and gravel wells and one bedrock well. These four compounds are trihalomethanes (THMs), which typically are formed as byproducts when chlorine or bromine is used to disinfect water. The maximum THM concentration detected was $4.2 \mu \mathrm{g} / \mathrm{L}$ for dibromochloromethane in a sample from a production sand and gravel well. The concentration of total THMs did not exceed the USEPA and NYSDOH MCLs of $80 \mu \mathrm{g} / \mathrm{L}$.

Of the remaining VOCs detected, which include 1,1,1-trichloroethane, 1,2-dichloroethane, ethylbenzene, $m$ - + $p$-Xylene, methyl tert-butyl ether (MTBE), tetrachloroethene, toluene, and trichloroethene, MTBE had the highest concentration at $0.9 \mu \mathrm{g} / \mathrm{L}$.

\section{Bacteria}

All samples were analyzed for total coliform, fecal coliform, Escherichia coli (E. coli), and heterotrophic bacteria. Samples collected on or before September 1, 2011, were analyzed using the presence or absence method; subsequent samples were analyzed using the membrane filtration method. Total coliform bacteria were detected in nine samples (table $1-9)$ : three from sand and gravel wells and six from bedrock wells; six of the positive results were in a presence or absence analysis and the remaining three were in membrane 
Table 4. Drinking-water standards and summary statistics for concentrations of trace elements and radionuclides in groundwater samples from western New York, 2011.

[All concentrations in micrograms per liter in unfiltered water except as noted. mrem/yr, millirem per year; No., number; pCi/L, picocuries per liter; <, less than; --, not applicable]

\begin{tabular}{|c|c|c|c|c|c|c|c|c|}
\hline Constituent & $\begin{array}{l}\text { Drinking- } \\
\text { water } \\
\text { standard }\end{array}$ & $\begin{array}{c}\text { No. of } \\
\text { samples } \\
\text { exceeding } \\
\text { standard }\end{array}$ & \multicolumn{3}{|c|}{ Sand and gravel (15 samples) } & \multicolumn{3}{|c|}{ Bedrock (16 samples) } \\
\hline Antimony & ${ }^{1,2} 6$ & 0 & $<.2$ & $<.2$ & .3 & $<.2$ & $<.2$ & .4 \\
\hline Arsenic & ${ }^{1,2} 10$ & 1 & $<.28$ & .58 & 14.1 & $<.09$ & .60 & 7.7 \\
\hline Beryllium & 1,24 & 0 & $<.02$ & $<.02$ & $<.02$ & $<.02$ & $<.02$ & .05 \\
\hline Boron, filtered & -- & -- & 6.6 & 31 & 473 & 6.3 & 78 & 439 \\
\hline Cadmium & 1,25 & 0 & $<.02$ & $<.05$ & .09 & $<.02$ & $<.05$ & .10 \\
\hline Chromium & 1,2100 & 0 & $<.21$ & $<.30$ & .37 & $<.21$ & $<.21$ & 14.3 \\
\hline Cobalt & -- & -- & $<.02$ & $<.02$ & .06 & $<.02$ & .02 & 1.0 \\
\hline Iron & 2,3300 & 10 & $<5$ & 16 & 4,030 & 23 & 228 & 8,030 \\
\hline Lead & ${ }^{4} 15$ & 0 & $<.04$ & .08 & 1.03 & .04 & .26 & 2.25 \\
\hline Lithium & -- & -- & 1.2 & 3.7 & 52.4 & 2.7 & 16.2 & 143 \\
\hline Manganese, filtered & $\begin{array}{r}2300 \\
350\end{array}$ & $\begin{array}{r}1 \\
12\end{array}$ & $<.2$ & 11.1 & 520 & .2 & 27.7 & 225 \\
\hline Manganese & $\begin{array}{r}2300 \\
350\end{array}$ & $\begin{array}{r}1 \\
12\end{array}$ & $<.2$ & 10.8 & 531 & .6 & 30.2 & 218 \\
\hline Molybdenum & -- & -- & $<.1$ & .4 & 18.2 & $<.1$ & .5 & 7.8 \\
\hline Nickel & -- & -- & $<.12$ & $<.19$ & 1.9 & $<.12$ & .25 & 10.1 \\
\hline Selenium & 1,250 & 0 & $<.05$ & .07 & .47 & $<.05$ & $<.05$ & .88 \\
\hline Gross beta radioactivity, $\mathrm{pCi} / \mathrm{L}$ & 1,24 mrem/yr & -- & $<.63$ & 1.6 & 9.8 & $<.65$ & 2.0 & 15.0 \\
\hline Radon-222, pCi/L & $\begin{array}{r}5300 \\
{ }^{6} 4,000\end{array}$ & $\begin{array}{r}16 \\
0\end{array}$ & 113 & 510 & 1,880 & 56 & 290 & 1,310 \\
\hline Uranium & 1,230 & 0 & $<.014$ & .077 & 1.04 & $<.014$ & .066 & 3.31 \\
\hline
\end{tabular}

${ }^{1}$ U.S. Environmental Protection Agency maximum contaminant level.

${ }^{2}$ New York State Department of Health maximum contaminant level.

${ }^{3}$ U.S. Environmental Protection Agency secondary drinking water standard.

${ }^{4}$ U.S. Environmental Protection Agency treatment technique.

${ }^{5}$ U.S. Environmental Protection Agency proposed maximum contaminant level.

${ }^{6}$ U.S. Environmental Protection Agency proposed alternative maximum contaminant level. 
filtration analysis. The USEPA and NYSDOH MCLs for total coliform bacteria are exceeded when 5 percent of finished water samples collected in 1 month test positive for total coliform (if 40 or more samples are collected per month) or when two samples are positive for total coliform (if fewer than 40 samples are collected per month). Fecal coliform and E. coli were not detected in any sample. Heterotrophic plate counts ranged from less than 1 to 212 colony-forming units per milliliter $(\mathrm{CFU} / \mathrm{mL})$; the USEPA MCL $(500 \mathrm{CFU} / \mathrm{mL})$ was not exceeded.

\section{Wells Sampled in 2006 and 2011}

Six of the wells sampled in 2011 (AG 265, E1903, E1904, GS 216, OL 19, and WO 351) were sampled previously in 2006 as part of the program. Of the 147 physiochemical properties and constituents that samples were analyzed for in 2011, 141 had also been included in the analysis in 2006 (tables 1-10 through 1-13). The difference between results from 2006 and 2011 for a single well were typically smaller than those between the results from different wells. In general, there were no detectable trends in constituent concentrations between 2006 and 2011.

\section{Summary}

In 2002, the U.S. Geological Survey began an assessment of groundwater quality in bedrock and sand and gravel aquifers throughout New York State in cooperation with the New York State Department of Environmental Conservation (NYSDEC). As a part of this assessment, portions of the Lake Erie and Niagara River Basin, the western Lake Ontario Basin, and the Allegheny River Basin in western New York were studied in 2006 and again in 2011. The 2011 study included analysis of 31 water samples collected from 16 production wells and 15 private residential wells from July through November 2011. Water samples were analyzed for 147 physiochemical properties and constituents that included major ions, nutrients, trace elements, radionuclides, pesticides, VOCs, and indicator bacteria. Six wells (AG 265, E1903, E1904, GS 216, OL 19, and WO 351) were tested in both studies, and a comparison was made of the results. The concentrations of most of the constituents changed little between 2006 and 2011.

The results indicate that groundwater generally is of acceptable quality, although at 30 of the 31 wells sampled, at least one of the following constituents was detected at a concentration that exceeded current or proposed Federal or New York State drinking-water standards: $\mathrm{pH}$ (two samples), sodium (eight samples), sulfate (three samples), total dissolved solids (nine samples), aluminum (two samples), arsenic (one sample), iron (ten samples), manganese (twelve samples), radon-222 (sixteen samples), benzene (one sample), and total coliform bacteria (nine samples). Existing drinking-water standards for color, chloride, fluoride, nitrate, nitrite, antimony, barium, beryllium, cadmium, chromium, copper, lead, mercury, selenium, silver, thallium, zinc, gross alpha radioactivity, uranium, fecal coliform, Escherichia coli, and heterotrophic bacteria were not exceeded in any of the samples collected. None of the pesticides analyzed exceeded existing drinkingwater standards.

\section{References Cited}

Butch, G.K., Murray, P.M., Hebert, G.J., and Weigel, J.F., 2003, Water resources data, New York, water year 2002: U.S. Geological Survey Water-Data Report NY-02-1, p. 502-520.

Childress, C.J.O., Foreman, W.T., Connor, B.F., and Maloney, T.J., 1999, New reporting procedures based on longterm method detection levels and some considerations for interpretations of water-quality data provided by the U.S. Geological Survey National Water Quality Laboratory: U.S. Geological Survey Open-File Report 99-193, 19 p.

Coates, D.R., 1966, Glaciated Appalachian Plateau-Till shadows on hills: Science, v. 152, p. 1617-1619.

Eckhardt, D.A., Reddy, J.E., and Shaw, S.B., 2009, Groundwater quality in central New York, 2007: U.S. Geological Survey Open-File Report 2009-1257, 40 p., at http://pubs. usgs.gov/of/2009/1257/.

Eckhardt, D.A., Reddy, J.E., and Tamulonis, K.L., 2007, Ground-water quality in the Genesee River Basin, New York, 2005-06: U.S. Geological Survey Open-File Report 2007-1093, 26 p., at http://pubs.usgs.gov/of/2007/1093/.

Eckhardt, D.A., Reddy, J.E., and Tamulonis, K.L., 2008, Ground-water quality in western New York, 2006: U.S. Geological Survey Open-File Report 2008-1140, 36 p., at http://pubs.usgs.gov/of/2008/1140/.

Fisher, D.W., Isachsen, Y.W., and Rickard, L.V., 1970, Geologic map of New York State: New York State Museum Map and Chart Series no. 15, Finger Lakes and Niagara sheets, scale 1:250,000.

Hem, J.D., 1985, Study and interpretation of the chemical characteristics of natural water ( $3 \mathrm{~d}$ ed.): U.S. Geological Survey Water-Supply Paper 2254, 264 p.

Hetcher-Aguila, K.K., 2005, Ground-water quality in the Chemung River Basin, New York, 2003: U.S. Geological Survey Open-File Report 04-1329, 19 p., at http://ny.water. usgs.gov/pubs/of/of041329/.

Hetcher-Aguila, K.K., and Eckhardt, D.A., 2006, Groundwater quality in the upper Susquehanna River basin, New York, 2004-05: U.S. Geological Survey Open-File Report 06-1161, 20 p., at http://pubs.usgs.gov/of/2006/1161/. 
Krieger, H.L., and Whittaker, E.L., 1980, Prescribed procedures for measurement of radioactivity in drinking water: U.S. Environmental Protection Agency EPA 600/4-80-032, [not paged].

New York State Department of Health, 2011, New York State Health Department public water systems regulations: Albany, N.Y., New York State Department of Health, [variously paged], accessed January 2012, at http:/www.health. state.ny.us/environmental/water/drinking/part5/tables.htm.

Nystrom, E.A., 2006, Ground-water quality in the Lake Champlain basin, New York, 2004: U.S. Geological Survey Open-File Report 06-1088, 22 p., at http://pubs.usgs.gov/ of/2006/1088/.

Nystrom, E.A., 2007a, Ground-water quality in the St. Lawrence River basin, New York, 2005-2006: U.S. Geological Survey Open-File Report 2007-1066, 33 p., at http://pubs. usgs.gov/of/2007/1066/.

Nystrom, E.A., 2007b, Ground-water quality in the Delaware River Basin, New York, 2001 and 2005-2006: U.S. Geological Survey Open-File Report 2007-1098, 36 p., at http:// pubs.usgs.gov/of/2007/1098/.

Nystrom, E.A., 2008, Ground-water quality in the Mohawk River Basin, New York, 2006: U.S. Geological Survey Open-File Report 2008-1086, 33 p., at http://pubs.usgs.gov/ of/2008/1086/.

Nystrom, E.A., 2009, Ground-water quality in the Upper Hudson River Basin, New York, 2007: U.S. Geological Survey Open-File Report 2009-1240, 37 p., at http://pubs.usgs.gov/ of $/ 2009 / 1240 /$.

Nystrom, E.A., 2010, Groundwater quality in the Lower Hudson River Basin, New York, 2008: U.S. Geological Survey Open-File Report 2010-1197, 39 p., at http://pubs.usgs.gov/ of/2010/1197/.

Nystrom, E.A., 2011, Groundwater quality in the Lake Champlain Basin, New York, 2009: U.S. Geological Survey Open-File Report 2011-1180, 42 p., at http://pubs.usgs.gov/ of/2011/1180/.

Nystrom, E.A., 2012, Groundwater quality in the Delaware and St. Lawrence River Basins, New York, 2010: U.S. Geological Survey Open-File Report 2011-1320, 58 p., at http:// pubs.usgs.gov/of/2011/1320/.

Nystrom, E.A., and Scott, T., 2013, Groundwater quality in the Mohawk River Basin, New York, 2011: U.S. Geological Survey Open-File Report 2013-1021, 43 p., at http://pubs. usgs.gov/of/2013/1021/.

Randall, A.D., 2001, Hydrogeologic framework of stratifieddrift aquifers in the glaciated Northeastern United States: U.S. Geological Survey Professional Paper 1415-B, 179 p.
Reddy, J.E., 2012, Groundwater quality in the Genesee River Basin, New York, 2010: U.S. Geological Survey OpenFile Report 2012-1135, 29 p., at http://pubs.usgs.gov/ of/2012/1135/.

Reddy, J.E., and Risen, A.J., 2012, Groundwater quality in the Upper Susquehanna River Basin, New York, 2009: U.S. Geological Survey Open-File Report 2012-1045, 30 p., at http://pubs.usgs.gov/of/2012/1045/.

Risen, A.J., and Reddy, J.E., 2011a, Groundwater quality in the Eastern Lake Ontario Basin, New York, 2008: U.S. Geological Survey Open-File Report 2011-1074, 32 p., at http:// pubs.usgs.gov/of/2011/1074/.

Risen, A.J., and Reddy, J.E., 2011b, Groundwater quality in the Chemung River Basin, New York, 2008: U.S. Geological Survey Open-File Report 2011-1112, 25 p., at http:// pubs.usgs.gov/of/2011/1112/.

U.S. Environmental Protection Agency, 1997, Guidelines for preparation of the comprehensive state water quality assessments 305(b) reports and electronic updates: U.S. Environmental Protection Agency, EPA 841-B-97-002A and EPA 841-B-97-002B, PL 95-217, 271 p.

U.S. Environmental Protection Agency, 1999, Proposed radon in drinking water rule: U.S. Environmental Protection Agency EPA 815-F-99-006, 6 p.

U.S. Environmental Protection Agency, 2002, Drinking-water advisory - Consumer acceptability advice and health effects analysis on sodium: U.S. Environmental Protection Agency EPA 822-R-02-032, 34 p.

U.S. Environmental Protection Agency, 2009, National primary drinking water standards and national secondary drinking water standards: U.S. Environmental Protection Agency EPA 816-F-09-0004, 6 p.

U.S. Geological Survey, [variously dated], National field manual for the collection of water-quality data: U.S. Geological Survey Techniques of Water-Resources Investigations, book 9, chaps. A1-A9, at http://pubs.water.usgs.gov/twri9A/. 


\section{Appendix 1. Data Tables}

1-1. Information on wells sampled in western New York, 2011

1-2. Compounds for which groundwater samples from western New York were analyzed but not detected, 2011

1-2. Compounds for which groundwater samples from western New York were analyzed but not detected, 2011

1-3. Physiochemical properties of groundwater samples from western New York, 2011 .....16

1-4. Concentrations of major ions in groundwater samples from western New York, 2011. 17

1-5. Concentrations of nutrients and total organic carbon in groundwater samples from western New York study, 2011

1-6. Concentrations of trace elements and radionuclides in groundwater samples from western New York, 2011

1-6. Concentrations of trace elements and radionuclides in groundwater samples from western New York, 2011.

1-7. Concentrations of pesticides detected in groundwater samples from western New York study, 2011

1-8. Concentrations of volatile organic compounds in groundwater samples from western New York study, 2011

1-9. Concentrations of bacteria in unfiltered groundwater samples from western New York, 2011

1-10. Physiochemical properties of and concentrations of major ions, nutrients and total organic carbon, and bacteria in groundwater samples collected in western New York, 2006 and 2011

1-11. Concentrations of trace elements and radionuclides in groundwater samples collected in western New York, 2006 and 2011

1-12. Concentrations of pesticides in groundwater samples collected in western New York, 2006 and 2011

1-12. Concentrations of pesticides in groundwater samples collected in western New York, 2006 and 2011 .

1-13. Concentrations of volatile organic compounds in groundwater samples collected in western New York, 2006 and 2011 
THIS PAGE INTENTIONALLY LEFT BLANK 
Table 1-1. Information on wells sampled in western New York, 2011.

[Well locations are shown in figure 1. BLS, below land surface; ft, feet; ID, U.S. Geological Survey site identification number; no., number; - , information not available]

\begin{tabular}{|c|c|c|c|c|c|c|}
\hline Well no. ${ }^{1}$ & ID & Date sampled & $\begin{array}{l}\text { Well depth, } \\
\text { in ft BLS }\end{array}$ & $\begin{array}{l}\text { Casing depth, } \\
\text { in ft BLS }\end{array}$ & Well type ${ }^{2}$ & Bedrock type \\
\hline \multicolumn{7}{|c|}{ Sand and gravel wells } \\
\hline AG 265 & 421300078160001 & $8 / 22 / 2011$ & 70 & - & $\mathrm{P}$ & - \\
\hline СТ 673 & 422128079025101 & $11 / 7 / 2011$ & 39 & 31 & $\mathrm{P}$ & - \\
\hline СТ 674 & 420126078372001 & $11 / 29 / 2011$ & 78 & - & $\mathrm{P}$ & - \\
\hline CT 675 & 420937078410001 & $11 / 29 / 2011$ & 60 & - & $\mathrm{P}$ & - \\
\hline CU 863 & 422112079305501 & $10 / 19 / 2011$ & - & - & $\mathrm{P}$ & - \\
\hline CU 865 & 421512079161602 & $10 / 27 / 2011$ & 60 & 58 & $\mathrm{P}$ & - \\
\hline CU1959 & 421024079042801 & $11 / 28 / 2011$ & 45 & 45 & $\mathrm{D}$ & - \\
\hline CU2131 & 420926079355501 & $11 / 8 / 2011$ & 52 & 32 & $\mathrm{P}$ & - \\
\hline E1903 & 423001078400001 & $9 / 28 / 2011$ & 177 & 141 & $\mathrm{P}$ & - \\
\hline E1904 & 425424078294802 & $8 / 3 / 2011$ & 45 & - & $\mathrm{P}$ & - \\
\hline E1909 & 423550078384201 & 9/29/2011 & 169.5 & 152.2 & $\mathrm{P}$ & - \\
\hline GS 216 & 425900078120001 & $8 / 4 / 2011$ & 69 & 56 & $\mathrm{P}$ & - \\
\hline NI1221 & 431459078581201 & $7 / 27 / 2011$ & 72 & - & $\mathrm{D}$ & - \\
\hline WO 351 & 423200078250001 & $9 / 28 / 2011$ & 36 & 36 & $\mathrm{P}$ & - \\
\hline WO 353 & 424550078183901 & $10 / 26 / 2011$ & 132 & 123.5 & $\mathrm{P}$ & - \\
\hline \multicolumn{7}{|c|}{ Bedrock wells } \\
\hline AG 745 & 420547078055001 & $8 / 22 / 2011$ & 218 & 46 & $\mathrm{D}$ & Shale, siltstone, and sandstone. \\
\hline CT1047 & 422453078441001 & $8 / 31 / 2011$ & 120 & 54 & $\mathrm{D}$ & Shale, siltstone, and sandstone. \\
\hline CT2104 & 422252078324901 & $8 / 31 / 2011$ & 90 & 20 & $\mathrm{D}$ & Shale, siltstone, and sandstone. \\
\hline CT2881 & 420328078265001 & $9 / 27 / 2011$ & 120 & 82 & $\mathrm{D}$ & Shale, siltstone, and sandstone. \\
\hline CU 864 & 422712079182301 & $10 / 19 / 2011$ & 85 & - & $\mathrm{P}$ & Shale, siltstone, and sandstone. \\
\hline CU1023 & 422501079200401 & $11 / 30 / 2011$ & 50 & 8.5 & $\mathrm{D}$ & Shale, siltstone, and sandstone. \\
\hline CU2530 & 422923079115701 & $10 / 18 / 2011$ & 85 & 50 & $\mathrm{D}$ & Shale, siltstone, and sandstone. \\
\hline E1312 & 430248078335601 & $8 / 30 / 2011$ & 26 & - & $\mathrm{D}$ & Shale, dolostone, and evaporites. \\
\hline E1811 & 424842078294401 & $8 / 3 / 2011$ & 60 & 20.5 & $\mathrm{D}$ & Shale, siltstone, and sandstone. \\
\hline E3393 & 423459078502801 & $7 / 26 / 2011$ & 100 & 65 & $\mathrm{D}$ & Shale, siltstone, and sandstone. \\
\hline GS 479 & 425339078112301 & $9 / 1 / 2011$ & 45 & 18.5 & $\mathrm{D}$ & Shale, siltstone, and sandstone. \\
\hline MO1452 & 431701077540801 & $10 / 25 / 2011$ & 48 & 26 & $\mathrm{D}$ & Shale, siltstone, and sandstone. \\
\hline NI1240 & 430926078412801 & $8 / 23 / 2011$ & 83 & 13 & $\mathrm{D}$ & Limestone and dolostone. \\
\hline OL 19 & 431230078023001 & $8 / 17 / 2011$ & 32 & - & $\mathrm{P}$ & Shale, siltstone, and sandstone. \\
\hline OL 40 & 430828078214101 & $8 / 17 / 2011$ & 75 & 55 & $\mathrm{P}$ & Shale, dolostone, and evaporites. \\
\hline OL 52 & 432022078005501 & $8 / 16 / 2011$ & 25 & 25 & $\mathrm{D}$ & Shale, siltstone, and sandstone. \\
\hline
\end{tabular}

'Prefix denotes county: AG, Allegany; CT, Cattaraugus; CU, Chautauqua; E, Erie; GS, Genesee; MO, Monroe; NI, Niagara; OL, Orleans; WO, Wyoming; number is local well-identification number assigned by U.S. Geological Survey.

${ }^{2}$ Well types: D, domestic; P, production. 
Table 1-2. Compounds for which groundwater samples from western New York were analyzed but not detected, 2011.

[A water year (WY) is the 12-month period from October 1 through September 30 of the following year; the WY is designated by the calendar year in which it ends. NWIS, U.S. Geological Survey National Water Information System]

\begin{tabular}{|c|c|c|c|}
\hline \multirow{2}{*}{$\begin{array}{c}\text { NWIS } \\
\text { parameter code }\end{array}$} & \multirow{2}{*}{ Constituent } & \multicolumn{2}{|c|}{ Laboratory reporting level } \\
\hline & & WY11 & WY12 \\
\hline \multicolumn{4}{|c|}{ Trace elements in unfiltered water, in micrograms per liter } \\
\hline 71900 & Mercury & .005 & .005 \\
\hline \multicolumn{4}{|c|}{ Pesticides in filtered water, in micrograms per liter } \\
\hline 82660 & 2,6-Diethylaniline & .006 & .006 \\
\hline 49260 & Acetochlor & .010 & .010 \\
\hline 46342 & Alachlor & .008 & .008 \\
\hline 34253 & alpha-HCH & .004 & .0040 \\
\hline 82686 & Azinphos-methyl & .120 & .12 \\
\hline 82673 & Benfluralin & .014 & .014 \\
\hline 82680 & Carbaryl & .060 & .06 \\
\hline 82674 & Carbofuran & .060 & .060 \\
\hline 38933 & Chlorpyrifos & .004 & .0036 \\
\hline 82687 & cis-Permethrin & .010 & .010 \\
\hline 82682 & DCPA & .008 & .0076 \\
\hline 62170 & Desulfinyl fipronil & .012 & .012 \\
\hline 62169 & Desulfinylfipronil amide & .029 & .029 \\
\hline 39572 & Diazinon & .006 & .0060 \\
\hline 39381 & Dieldrin & .008 & .008 \\
\hline 82677 & Disulfoton & .04 & .040 \\
\hline 82668 & EPTC & .006 & .0056 \\
\hline 82663 & Ethalfluralin & .006 & .006 \\
\hline 82672 & Ethoprop & .016 & .016 \\
\hline 62166 & Fipronil & .018 & .018 \\
\hline 62167 & Fipronil sulfide & .012 & .012 \\
\hline 62168 & Fipronil sulfone & .024 & .024 \\
\hline 04095 & Fonofos & .005 & .0048 \\
\hline 39341 & Lindane & .004 & .0040 \\
\hline 82666 & Linuron & .060 & .06 \\
\hline 39532 & Malathion & .016 & .016 \\
\hline 82630 & Metribuzin & .012 & .012 \\
\hline 82671 & Molinate & .004 & .0040 \\
\hline 82684 & Napropamide & .008 & .008 \\
\hline 34653 & $p, p^{\prime}-\mathrm{DDE}$ & .002 & .002 \\
\hline 39542 & Parathion & .020 & .020 \\
\hline 82667 & Methyl parathion & .008 & .008 \\
\hline 82669 & Pebulate & .016 & .016 \\
\hline 82683 & Pendimethalin & .012 & .012 \\
\hline 82664 & Phorate & .020 & .020 \\
\hline 04024 & Propachlor & .006 & .006 \\
\hline 82679 & Propanil & .010 & .010 \\
\hline 82685 & Propargite & .02 & .020 \\
\hline
\end{tabular}


Table 1-2. Compounds for which groundwater samples from western New York were analyzed but not detected, 2011.—Continued [A water year (WY) is the 12-month period from October 1 through September 30 of the following year; the WY is designated by the calendar year in which it ends. NWIS, U.S. Geological Survey National Water Information System]

\begin{tabular}{|c|c|c|c|}
\hline \multirow{2}{*}{$\begin{array}{c}\text { NWIS } \\
\text { parameter code }\end{array}$} & \multirow{2}{*}{ Constituent } & \multicolumn{2}{|c|}{ Laboratory reporting level } \\
\hline & & WY11 & WY12 \\
\hline 82676 & Propyzamide & .004 & .0036 \\
\hline 82675 & Terbufos & .02 & .018 \\
\hline 82681 & Thiobencarb & .016 & .016 \\
\hline 82678 & Triallate & .005 & .0046 \\
\hline 82661 & Trifluralin & .018 & .018 \\
\hline \multicolumn{4}{|c|}{ Volatile organic compounds in unfiltered water, in micrograms per liter } \\
\hline 77652 & 1,1,1-Trichloro-1,2,2-trifluoroethane & .1 & .1 \\
\hline 34496 & 1,1-Dichloroethane & .1 & .1 \\
\hline 34501 & 1,1-Dichloroethene & .1 & .1 \\
\hline 34536 & 1,2-Dichlorobenzene & .1 & .1 \\
\hline 34541 & 1,2-Dichloropropane & .1 & .1 \\
\hline 34566 & 1,3-Dichlorobenzene & .1 & .1 \\
\hline 34571 & 1,4-Dichlorobenzene & .1 & .1 \\
\hline 34301 & Chlorobenzene & .1 & .1 \\
\hline 77093 & cis-1,2-Dichloroethene & .1 & .1 \\
\hline 34668 & Dichlorodifluoromethane & .2 & .2 \\
\hline 34423 & Dichloromethane & .2 & .2 \\
\hline 81576 & Diethyl ether & .2 & .2 \\
\hline 81577 & Diisopropyl ether & .2 & .2 \\
\hline 50004 & tert-Butyl ethyl ether & .1 & .1 \\
\hline 77135 & $o$-Xylene & .1 & .1 \\
\hline 77128 & Styrene & .1 & .1 \\
\hline 50005 & Methyl tert-pentyl ether & .2 & .2 \\
\hline 32102 & Tetrachloromethane & .2 & .2 \\
\hline 34546 & trans-1,2-Dichloroethene & .1 & .1 \\
\hline 34488 & Trichlorofluoromethane & .2 & .2 \\
\hline 39175 & Vinyl chloride & .2 & .2 \\
\hline
\end{tabular}


Table 1-3. Physiochemical properties of groundwater samples from western New York, 2011.

[Well locations are shown in figure 1. Bold values exceed one or more drinking-water standard. (00080), U.S. Geological Survey (USGS) National Water Information System (NWIS) parameter code; no., number; mg/L, milligrams per liter; $\mu \mathrm{S} / \mathrm{cm} @ 25^{\circ} \mathrm{C}$, microsiemens per centimeter at $25^{\circ} \mathrm{C} ;<$, less than; ${ }^{\circ} \mathrm{C}$, degrees Celsius]

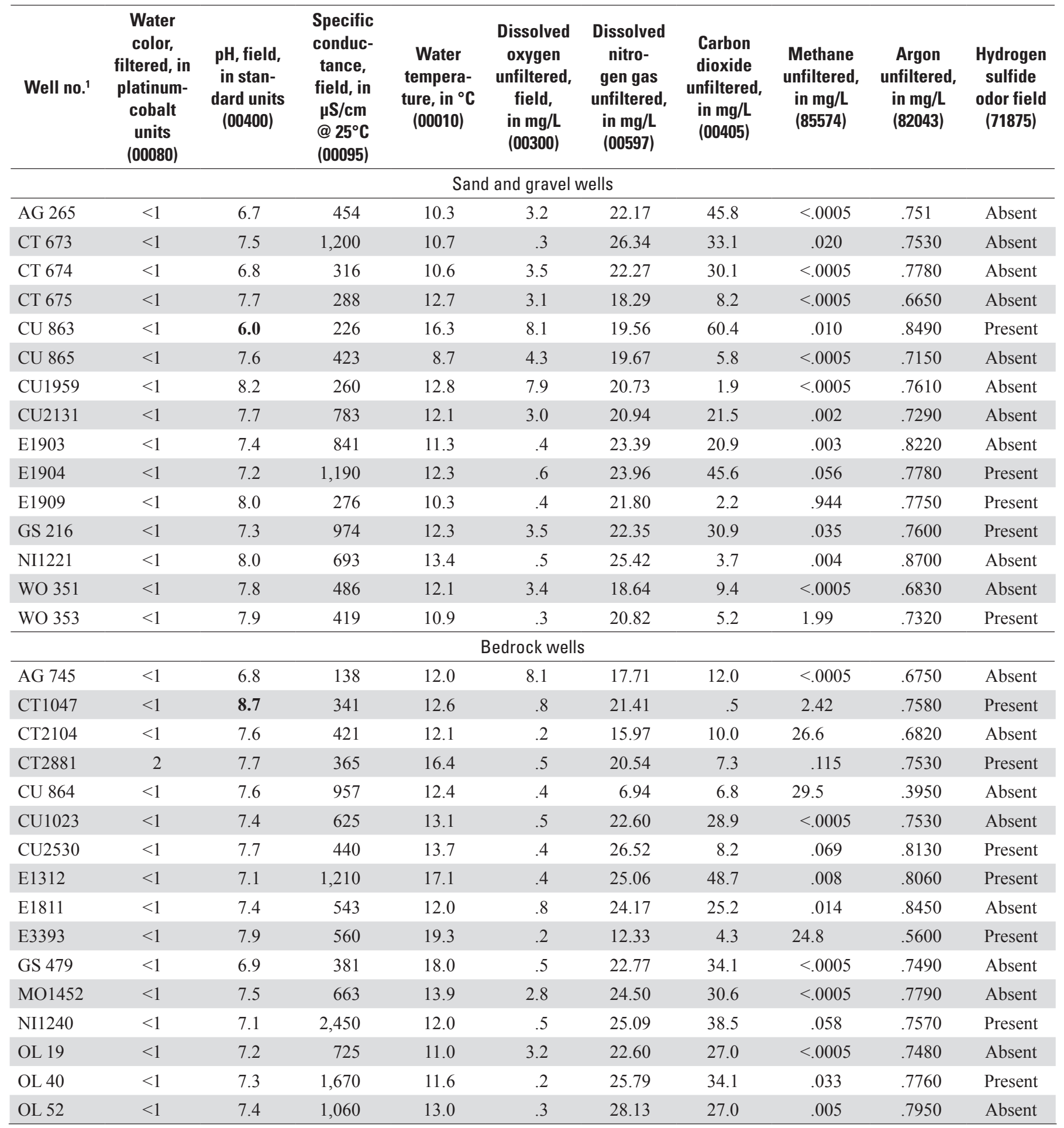

'Prefix denotes county: AG, Allegany; CT, Cattaraugus; CU, Chautauqua; E, Erie; GS, Genesee; MO, Monroe; NI, Niagara; OL, Orleans; WO, Wyoming; number is local well-identification number assigned by the USGS. 


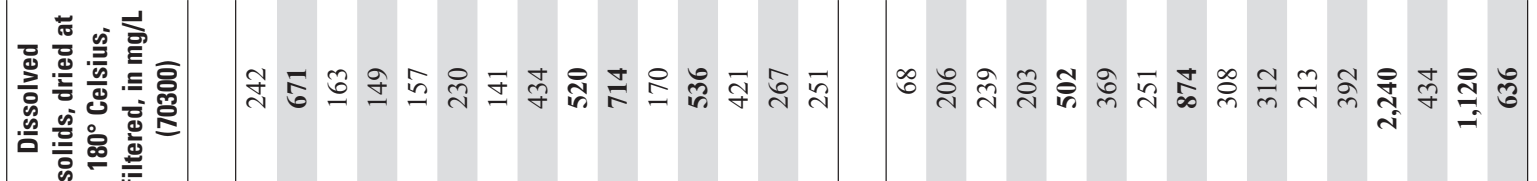

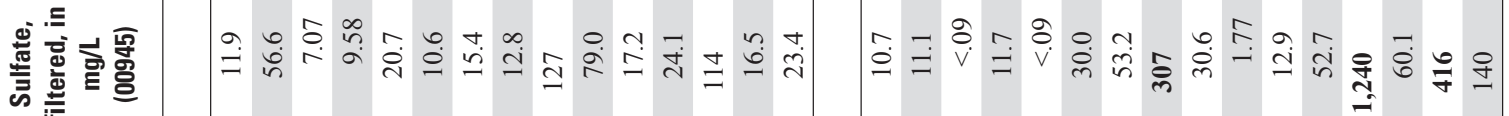

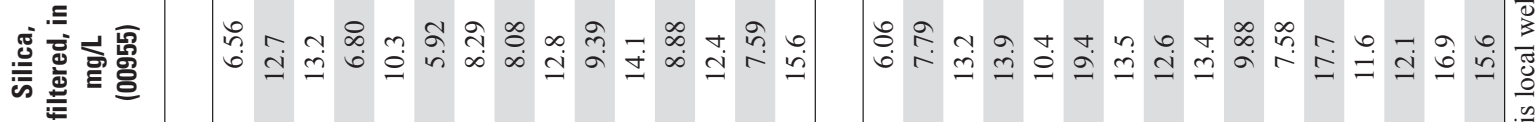

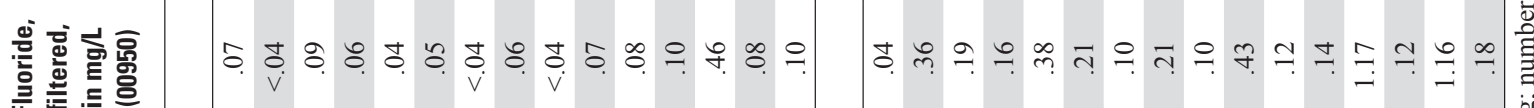

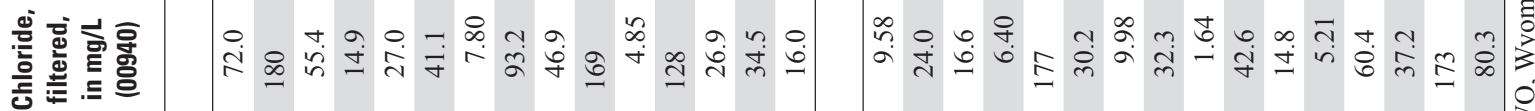

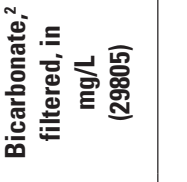

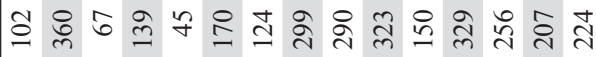

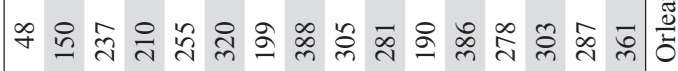

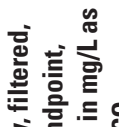
竞 离

$0^{3}$

赵密

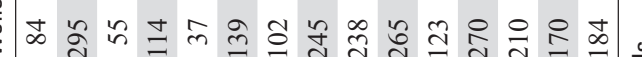

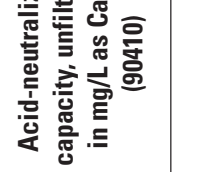

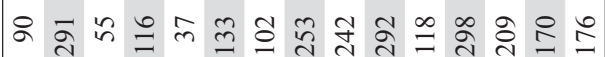

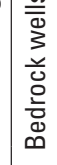

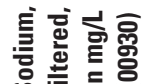

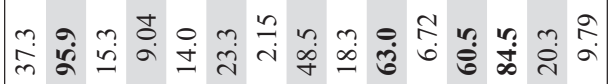

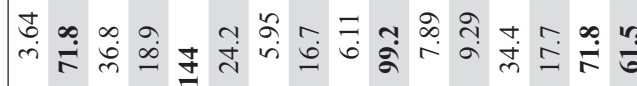


Table 1-5. Concentrations of nutrients and total organic carbon in groundwater samples from western New York study, 2011.

[Well locations are shown in figure 1. mg/L, milligrams per liter; N, nitrogen; no., number; (00623), U.S. Geological Survey (USGS) National Water Information System (NWIS) parameter code; P, phosphorus; <, less than]

\begin{tabular}{|c|c|c|c|c|c|c|}
\hline Well no. ${ }^{1}$ & $\begin{array}{c}\text { Ammonia plus } \\
\text { organic nitrogen, } \\
\text { filtered, in } \mathrm{mg} / \mathrm{L} \\
\text { as } \mathrm{N} \\
(00623)\end{array}$ & $\begin{array}{l}\text { Ammonia, } \\
\text { filtered, in mg/L } \\
\text { as } N \\
(00608)\end{array}$ & $\begin{array}{l}\text { Nitrate plus } \\
\text { nitrite, filtered, in } \\
\mathrm{mg} / \mathrm{L} \text { as } \mathrm{N} \\
(00631)\end{array}$ & $\begin{array}{l}\text { Nitrite, filtered, in } \\
\mathrm{mg} / \mathrm{L} \text { as } \mathrm{N} \\
(00613)\end{array}$ & $\begin{array}{l}\text { Orthophosphate, } \\
\text { filtered, in } \mathrm{mg} / \mathrm{L} \\
\text { as } \mathrm{P} \\
(00671)\end{array}$ & $\begin{array}{c}\text { Total organic } \\
\text { carbon, unfil- } \\
\text { tered, in mg/L } \\
\quad(00680)\end{array}$ \\
\hline \multicolumn{7}{|c|}{ Sand and gravel wells } \\
\hline AG 265 & $<.05$ & $<.010$ & 1.96 & $<.001$ & .025 & $<.3$ \\
\hline СТ 673 & .28 & .158 & $<.04$ & .001 & $<.004$ & 1.6 \\
\hline СТ 674 & .10 & $<.010$ & .23 & $<.001$ & .035 & $<.5$ \\
\hline CT 675 & $<.07$ & $<.010$ & .71 & $<.001$ & .009 & $<.5$ \\
\hline CU 863 & $<.07$ & $<.010$ & 1.32 & $<.001$ & .007 & $<.5$ \\
\hline CU 865 & .07 & $<.010$ & 1.57 & $<.001$ & $<.004$ & $<.5$ \\
\hline CU1959 & $<.07$ & $<.010$ & 1.44 & $<.001$ & .014 & $<.5$ \\
\hline CU2131 & $<.07$ & .011 & 1.30 & $<.001$ & $<.004$ & $<.5$ \\
\hline E1903 & .11 & .050 & $<.02$ & $<.001$ & .010 & $<.3$ \\
\hline E1904 & .23 & .164 & .03 & $<.001$ & $<.004$ & 1.3 \\
\hline E1909 & .12 & .085 & $<.02$ & $<.001$ & .029 & $<.3$ \\
\hline GS 216 & .07 & .011 & .62 & $<.001$ & $<.004$ & $<.3$ \\
\hline NI1221 & .26 & .251 & $<.02$ & $<.001$ & .011 & .7 \\
\hline WO 351 & .08 & $<.010$ & 1.3 & $<.001$ & .009 & $<.3$ \\
\hline WO 353 & .22 & .148 & $<.04$ & $<.001$ & .018 & $<.5$ \\
\hline \multicolumn{7}{|c|}{ Bedrock wells } \\
\hline AG 745 & $<.05$ & $<.010$ & .24 & $<.001$ & .014 & $<.3$ \\
\hline CT1047 & .25 & .167 & $<.02$ & $<.001$ & .031 & .3 \\
\hline CT2104 & .17 & .154 & $<.02$ & $<.001$ & .014 & $<.3$ \\
\hline CT2881 & .16 & .103 & $<.02$ & $<.001$ & .008 & $<.3$ \\
\hline CU 864 & 1.2 & 1.01 & $<.04$ & $<.001$ & .005 & $<.5$ \\
\hline CU1023 & .10 & .049 & .04 & .005 & .005 & 1.0 \\
\hline CU2530 & .09 & .039 & $<.04$ & $<.001$ & $<.004$ & $<.5$ \\
\hline E1312 & .08 & .017 & $<.02$ & $<.001$ & .005 & 1.5 \\
\hline E1811 & .17 & .109 & $<.02$ & $<.001$ & .004 & 1.1 \\
\hline E3393 & .65 & .658 & $<.02$ & $<.001$ & .012 & .3 \\
\hline GS 479 & .15 & .020 & .67 & .010 & .004 & 1.9 \\
\hline MO1452 & .12 & $<.010$ & 2.74 & $<.001$ & .005 & 1.1 \\
\hline NI1240 & .31 & .272 & .06 & $<.001$ & .006 & 1.0 \\
\hline OL 19 & .07 & $<.010$ & 1.76 & $<.001$ & .005 & 1.1 \\
\hline OL 40 & .07 & .052 & .03 & .001 & .007 & .8 \\
\hline OL 52 & .25 & .162 & .09 & .001 & .013 & 1.5 \\
\hline
\end{tabular}

'Prefix denotes county: AG, Allegany; CT, Cattaraugus; CU, Chautauqua; E, Erie; GS, Genesee; MO, Monroe; NI, Niagara; OL, Orleans; WO, Wyoming; number is local well-identification number assigned by the USGS. 


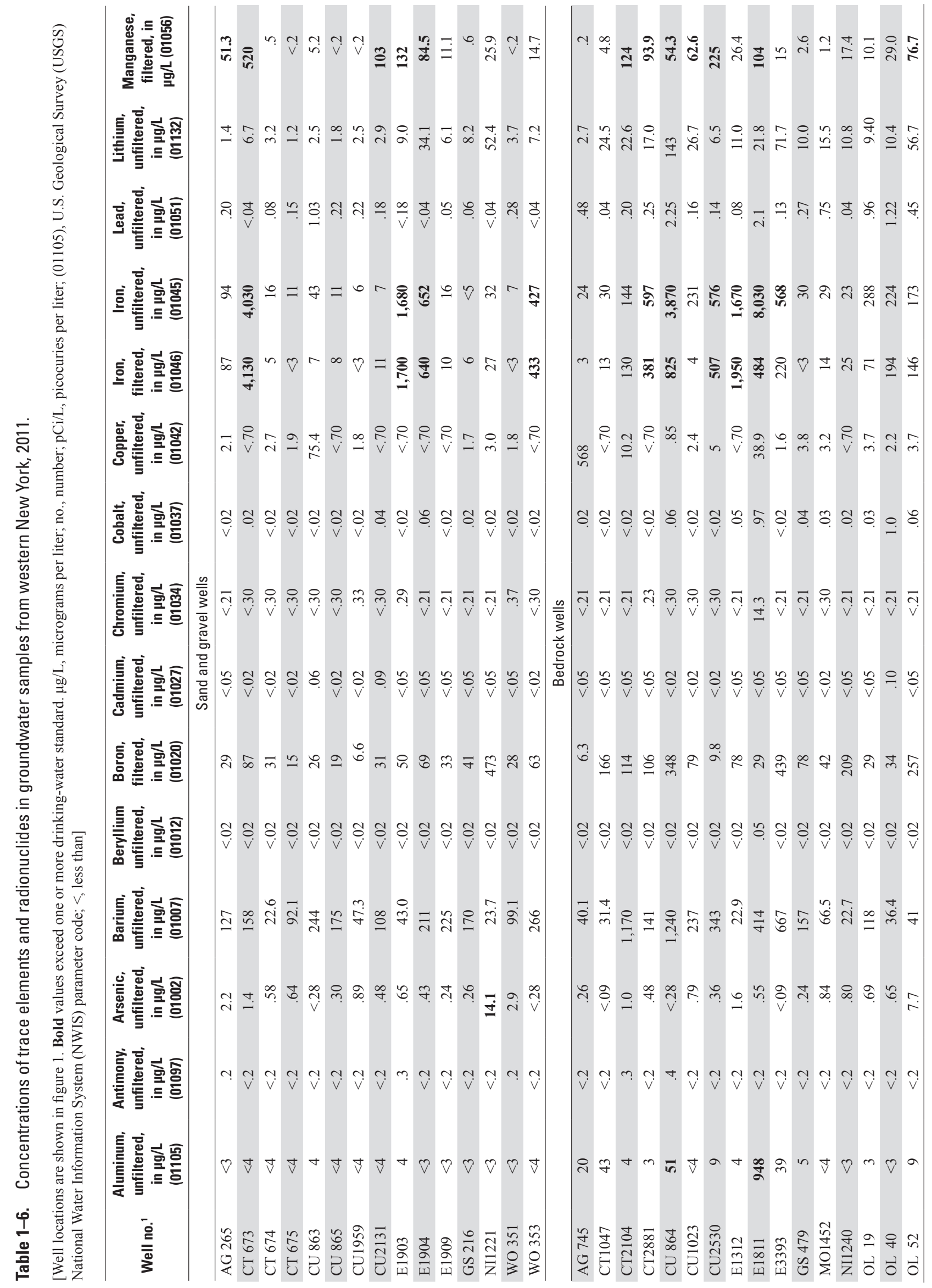




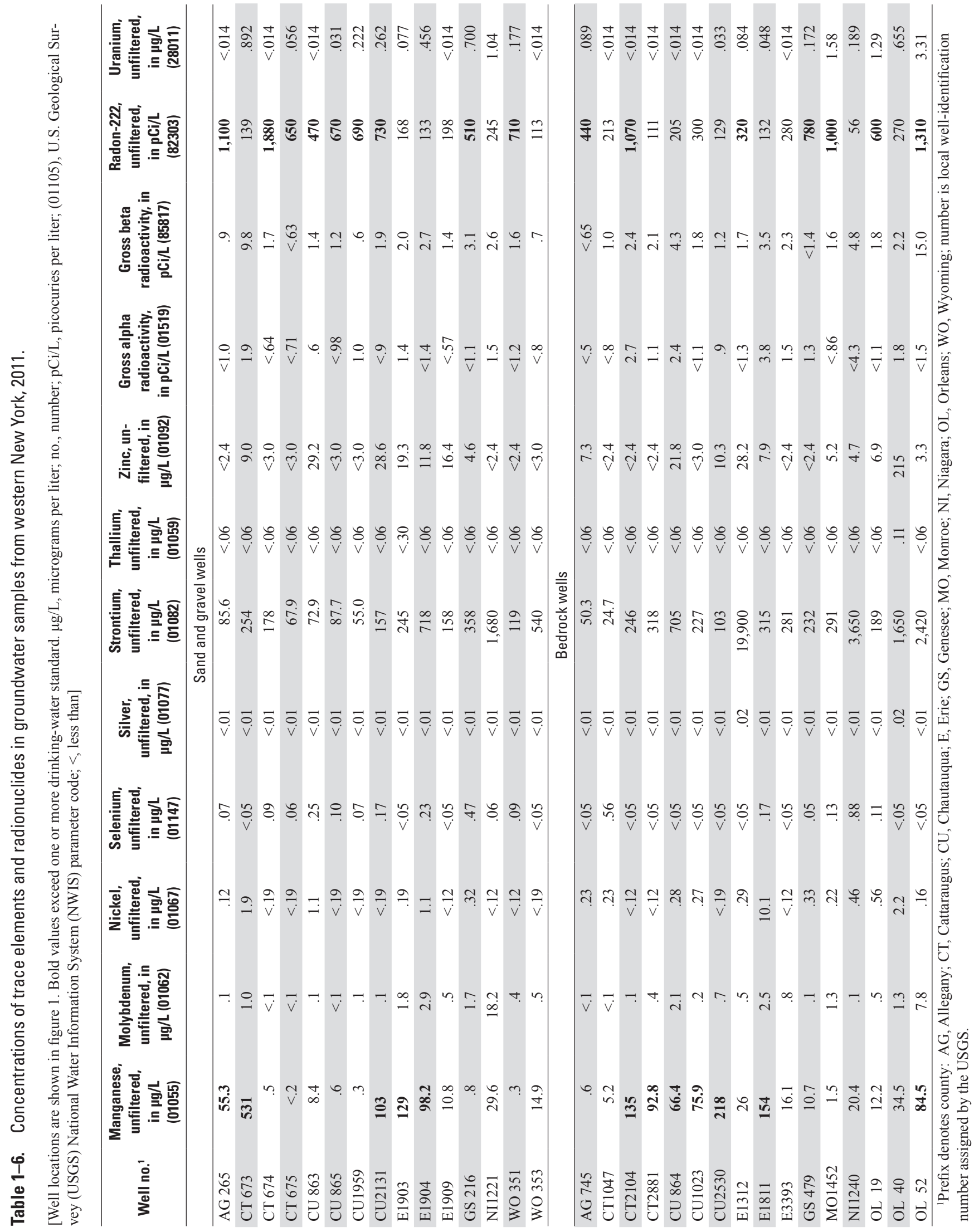


Table 1-7. Concentrations of pesticides detected in groundwater samples from western New York study, 2011.

[Well locations are shown in figure 1. Bold values indicate detected concentration. CIAT, deethylatrazine; e, estimated value (constituent was detected in the sample but with low or inconsistent recovery); M, presence verified but not quantified; $\mu \mathrm{g} / \mathrm{L}$, micrograms per liter; (04040), U.S. Geological Survey (USGS) National Water Information System (NWIS) parameter code; <, less than]

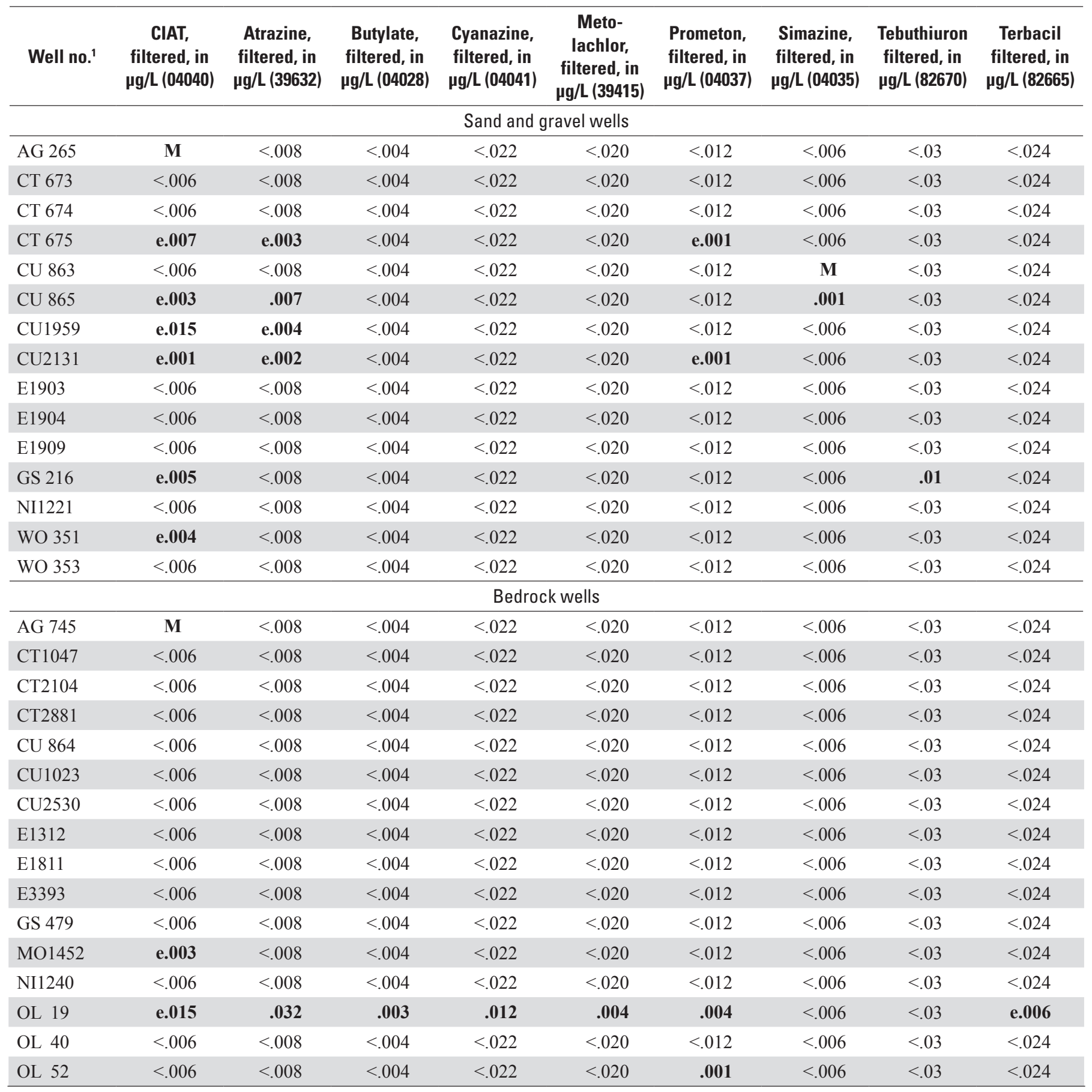

${ }^{1}$ Prefix denotes county: AG, Allegany; CT, Cattaraugus; CU, Chautauqua; E, Erie; GS, Genesee; MO, Monroe; NI, Niagara; OL, Orleans; WO, Wyoming; number is local well-identification number assigned by the USGS. 


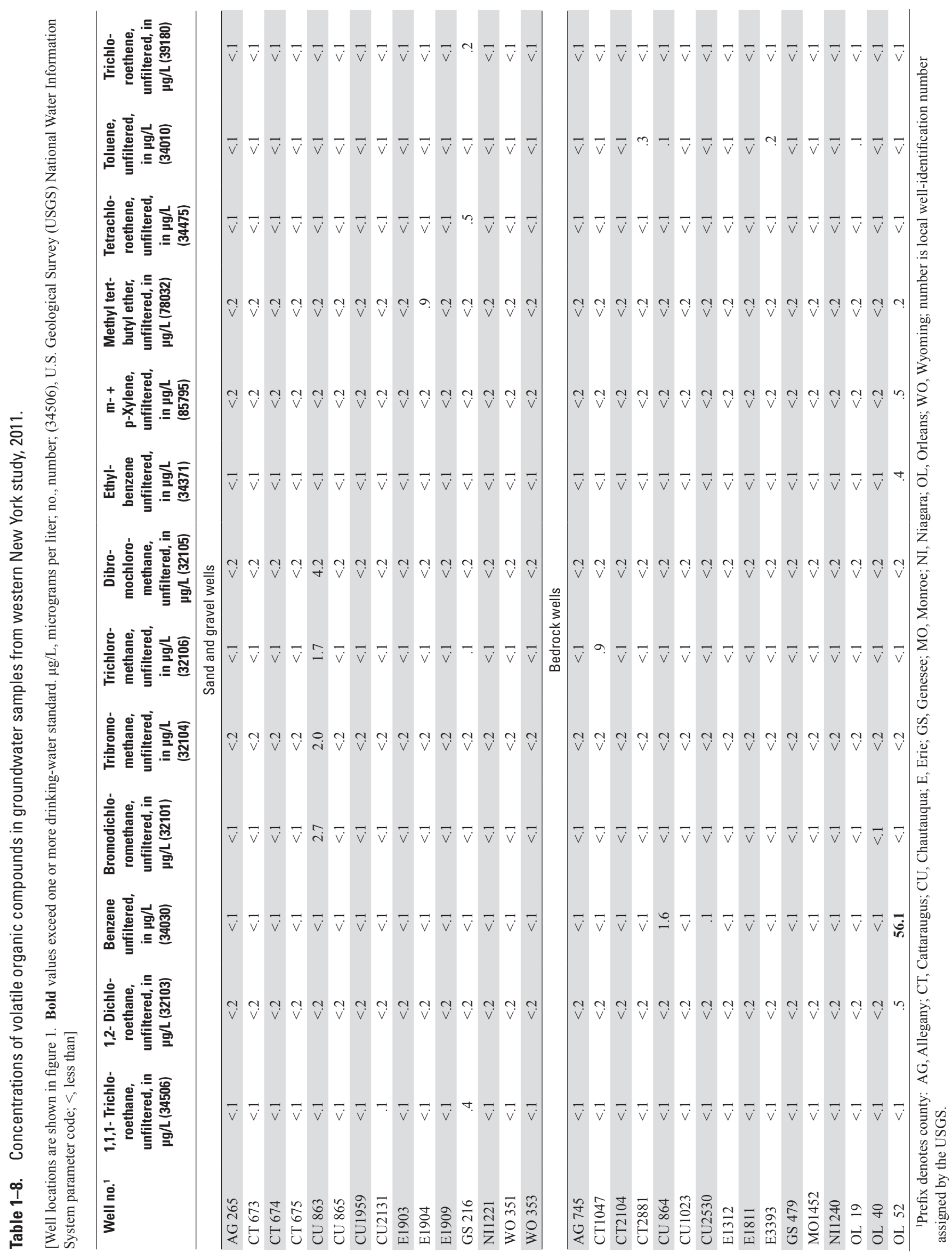


Table 1-9. Concentrations of bacteria in unfiltered groundwater samples from western New York, 2011.

[Well locations are shown in figure 1. Bold values indicate detections of coliform bacteria. CFU/mL, colony-forming unit per milliliter; $\mathrm{mL}$, milliliter; M, present; no., number; U, absent; (99595), U.S. Geological Survey (USGS) National Water Information System (NWIS) parameter code; - , not applicable; $<$, less than]

\begin{tabular}{|c|c|c|c|c|c|c|}
\hline Well no. ${ }^{1}$ & $\begin{array}{c}\text { Total coliform, } \\
\text { Colilert, pres- } \\
\text { ence/absence } \\
\text { (99595) }\end{array}$ & $\begin{array}{c}\text { Total coliform, } \\
\text { membrane filtra- } \\
\text { tion, in colonies } \\
\text { per } 100 \mathrm{~mL} \text { (61213) }\end{array}$ & $\begin{array}{l}\text { Fecal coliform, in } \\
\text { colonies per } 100 \\
\text { mL (61215) }\end{array}$ & $\begin{array}{c}\text { Escherichia coli, } \\
\text { Colilert, pres- } \\
\text { ence/absence } \\
(99596)\end{array}$ & $\begin{array}{l}\text { Escherichia coli, } \\
\text { in colonies per } \\
100 \mathrm{~mL}(31691)\end{array}$ & $\begin{array}{l}\text { Heterotrophic } \\
\text { plate count, in } \\
\text { CFU/mL (31692) }\end{array}$ \\
\hline \multicolumn{7}{|c|}{ Sand and gravel wells } \\
\hline AG 265 & $\mathbf{M}$ & - & $<1$ & $\mathrm{U}$ & - & 13 \\
\hline CT 673 & - & $<1$ & $<1$ & - & $<1$ & 4 \\
\hline CT 674 & - & $<1$ & $<1$ & - & $<1$ & 4 \\
\hline CT 675 & - & $<1$ & $<1$ & - & $<1$ & 2 \\
\hline CU 863 & - & $<1$ & $<1$ & - & $<1$ & 2 \\
\hline CU 865 & - & $<1$ & $<1$ & - & $<1$ & 3 \\
\hline CU1959 & - & 21 & $<1$ & - & $<1$ & 39 \\
\hline CU2131 & - & $<1$ & $<1$ & - & $<1$ & $<1$ \\
\hline E1903 & - & $<1$ & $<1$ & - & $<1$ & 2 \\
\hline E1904 & $\mathrm{U}$ & - & $<1$ & $\mathrm{U}$ & - & 2 \\
\hline E1909 & - & $<1$ & $<1$ & - & $<1$ & 8 \\
\hline GS 216 & $\mathrm{U}$ & - & $<1$ & $\mathrm{U}$ & - & 2 \\
\hline NI1221 & $\mathrm{U}$ & - & $<1$ & $\mathrm{U}$ & - & 56 \\
\hline WO 351 & - & 21 & $<1$ & - & $<1$ & 31 \\
\hline WO 353 & - & $<1$ & $<1$ & - & $<1$ & 2 \\
\hline \multicolumn{7}{|c|}{ Bedrock wells } \\
\hline AG 745 & $\mathrm{U}$ & - & $<1$ & $\mathrm{U}$ & - & 1 \\
\hline CT1047 & $\mathbf{M}$ & - & $<1$ & $\mathrm{U}$ & - & 9 \\
\hline CT2104 & $\mathbf{M}$ & - & $<1$ & $\mathrm{U}$ & - & 6 \\
\hline CT2881 & - & $<1$ & $<1$ & - & $<1$ & 40 \\
\hline CU 864 & - & $<1$ & $<1$ & - & $<1$ & 2 \\
\hline CU1023 & - & $<1$ & $<1$ & - & $<1$ & 1 \\
\hline CU2530 & - & $<1$ & $<1$ & - & $<1$ & 24 \\
\hline E1312 & $\mathbf{M}$ & - & $<1$ & $\mathrm{U}$ & - & 12 \\
\hline E1811 & $\mathbf{M}$ & - & $<1$ & $\mathrm{U}$ & - & 212 \\
\hline E3393 & $\mathrm{U}$ & - & $<1$ & $\mathrm{U}$ & - & 2 \\
\hline GS 479 & $\mathrm{U}$ & - & $<1$ & $\mathrm{U}$ & - & 3 \\
\hline MO1452 & - & 25 & $<1$ & - & $<1$ & 41 \\
\hline NI1240 & $\mathrm{U}$ & - & $<1$ & $\mathrm{U}$ & - & $<1$ \\
\hline OL 19 & $\mathrm{U}$ & - & $<1$ & $\mathrm{U}$ & - & 5 \\
\hline OL 40 & $\mathrm{U}$ & - & $<1$ & $\mathrm{U}$ & - & 4 \\
\hline OL 52 & $\mathbf{M}$ & - & $<1$ & $\mathrm{U}$ & - & 28 \\
\hline
\end{tabular}

'Prefix denotes county: AG, Allegany; CT, Cattaraugus; CU, Chautauqua; E, Erie; GS, Genesee; MO, Monroe; NI, Niagara; OL, Orleans; WO, Wyoming; number is local well-identification number assigned by the USGS. 


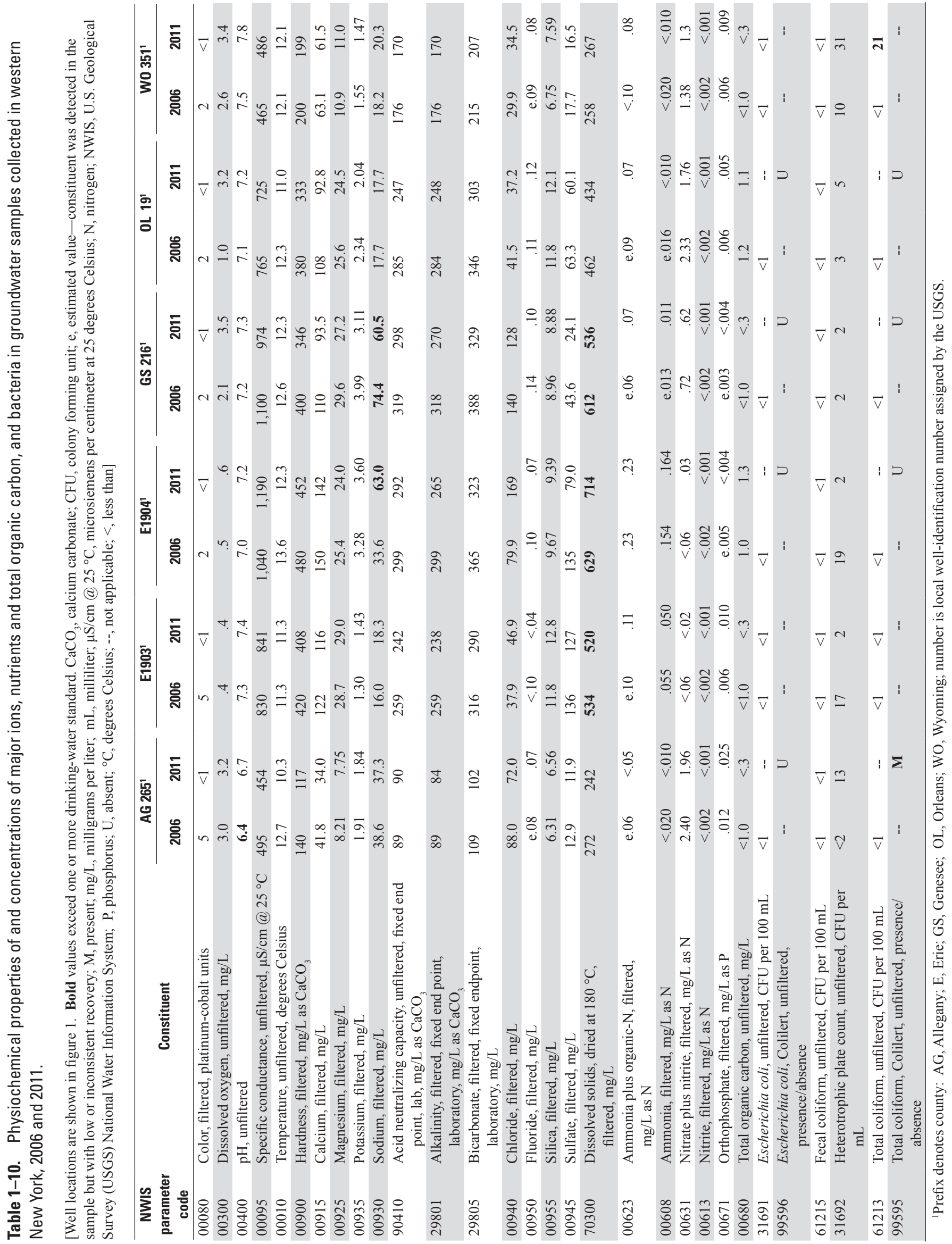


$\dot{\circ}$ is

क्ष

당

$\stackrel{2}{\overparen{2}}$

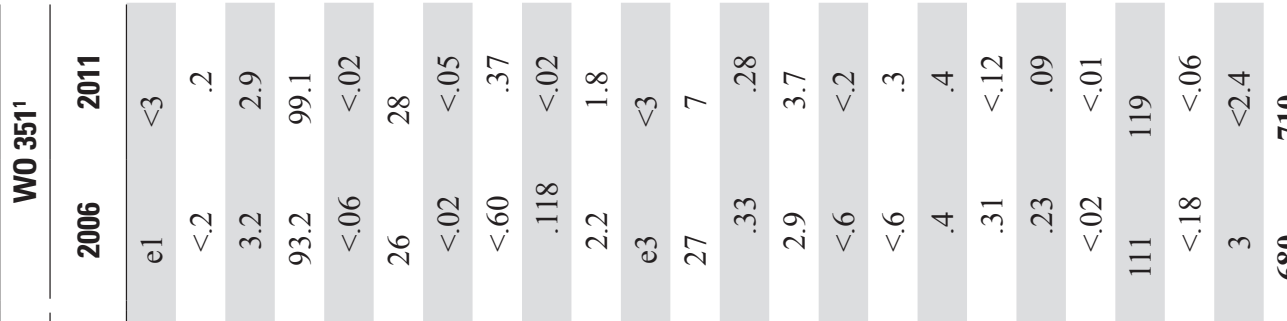

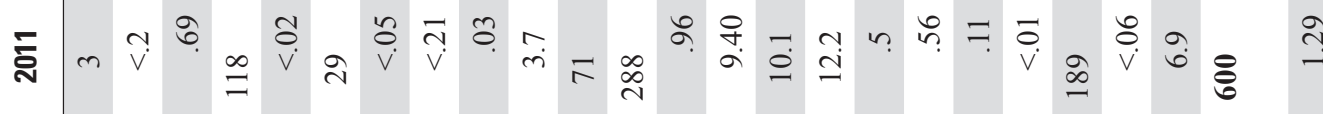

o

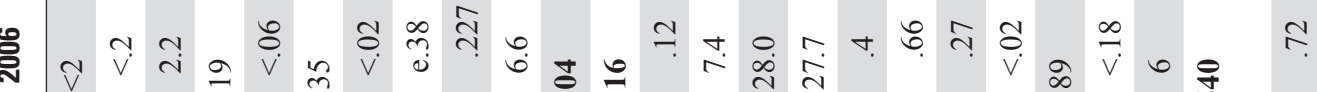

焉

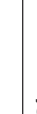

要

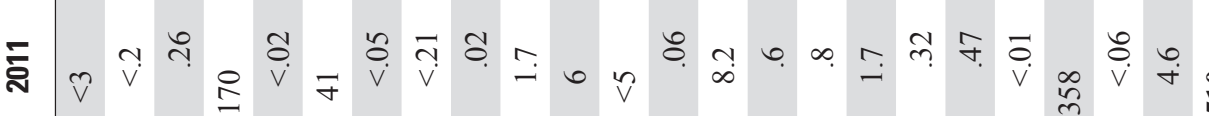

产

¿

$\sqrt{5}$

望.

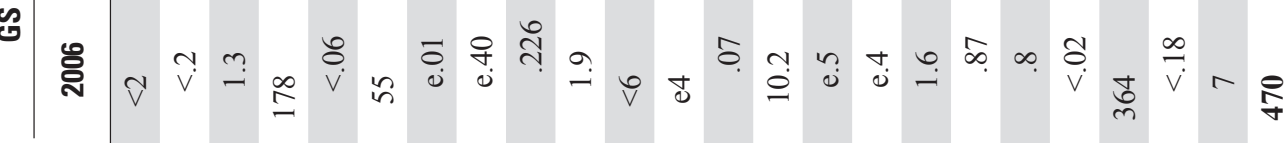

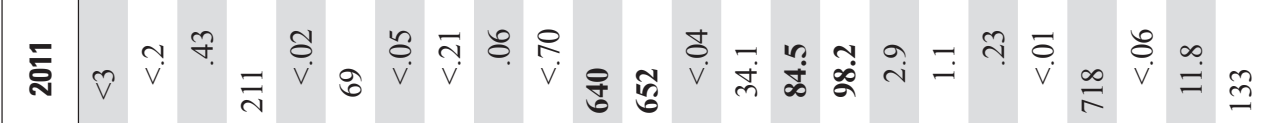

兽

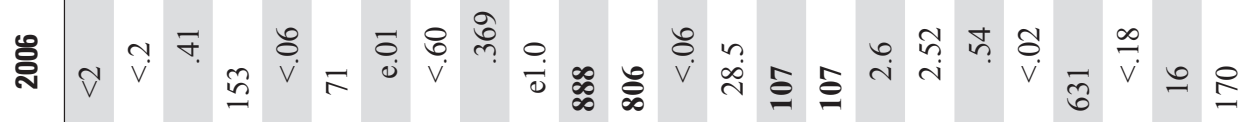

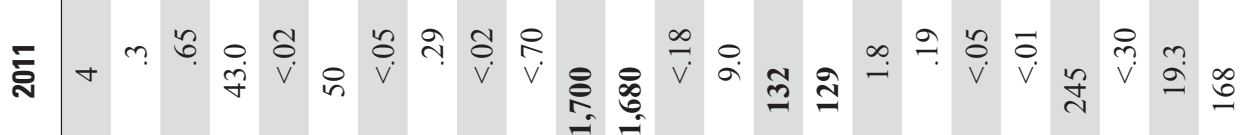

$\gtreqless$

跣

8

政

这

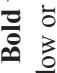

离

兘

은

.

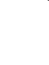

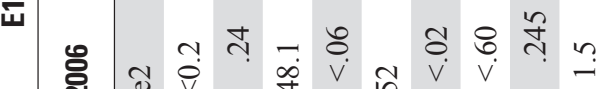

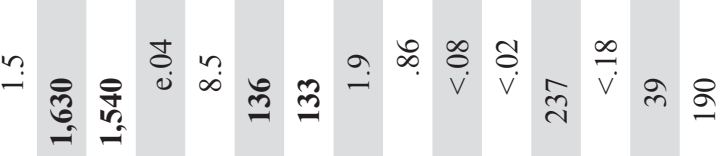

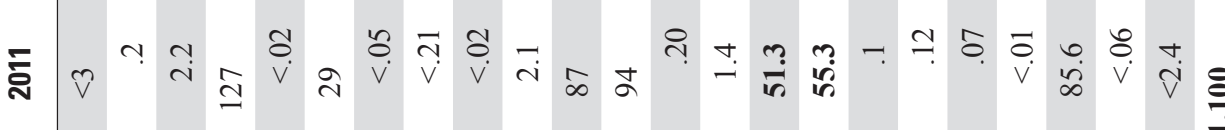

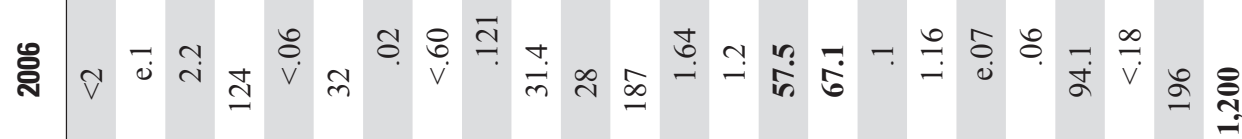




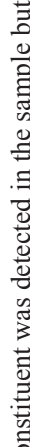

施

突

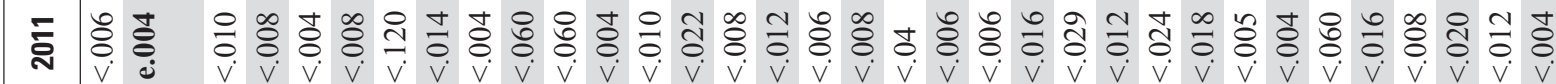

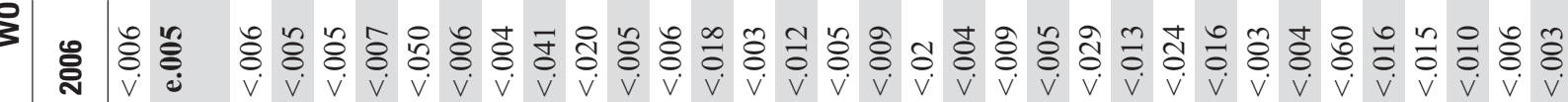

సَำ

อิ

舟

$\bar{\Phi} v$

焉

i. कี

.

过

产

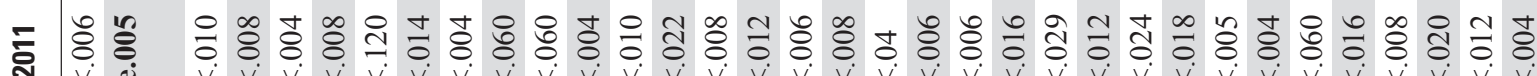

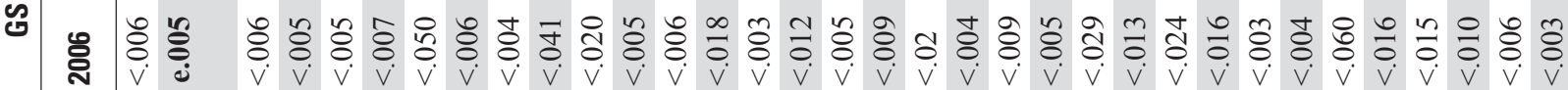

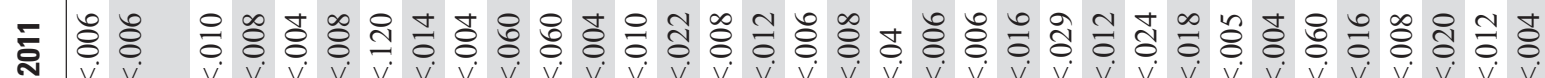

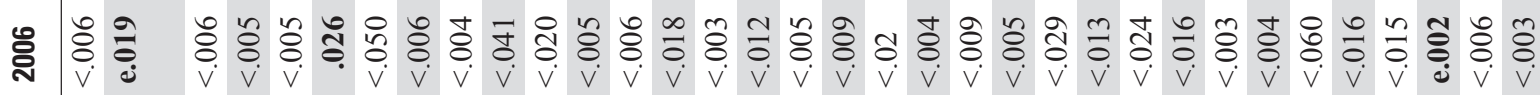

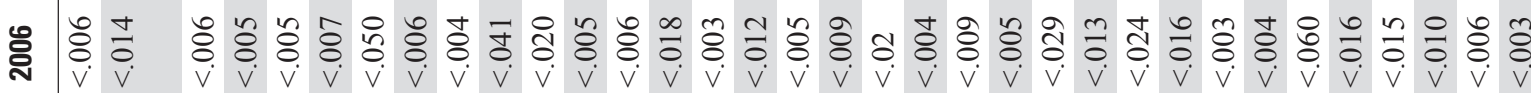

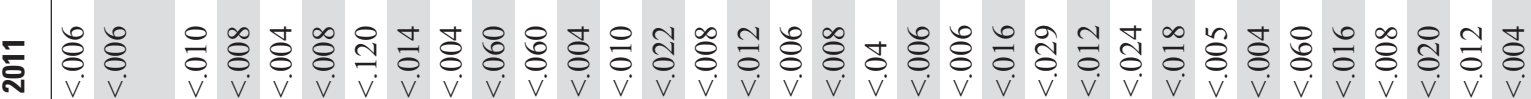

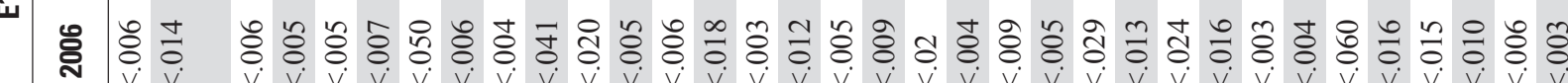

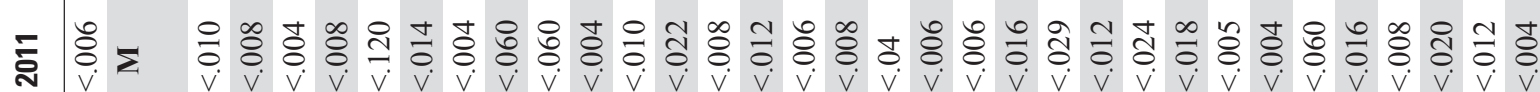

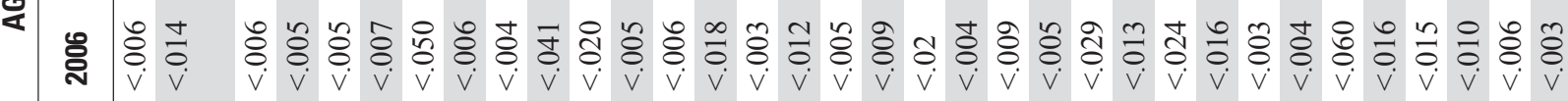

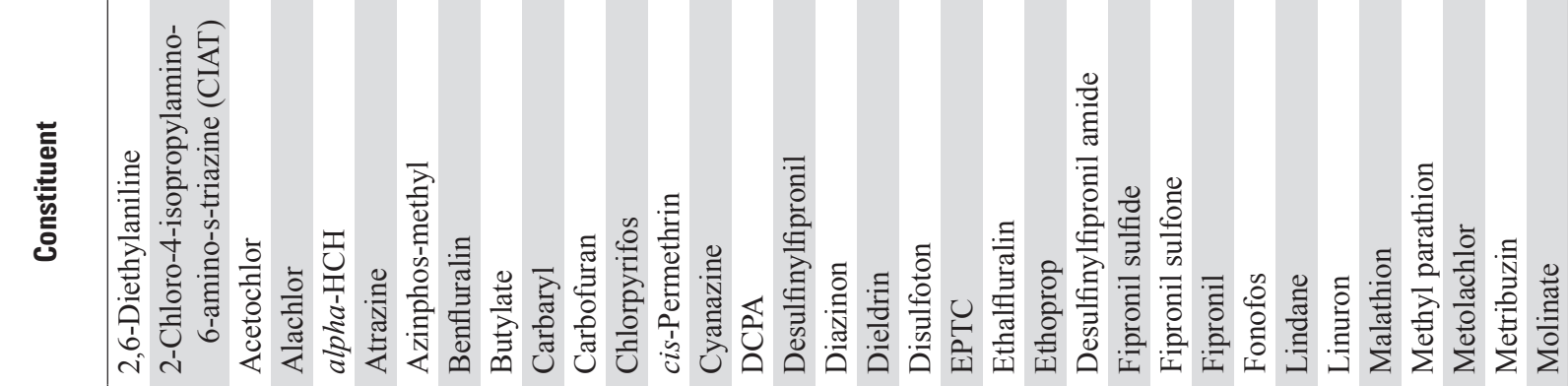

是

竞离青 


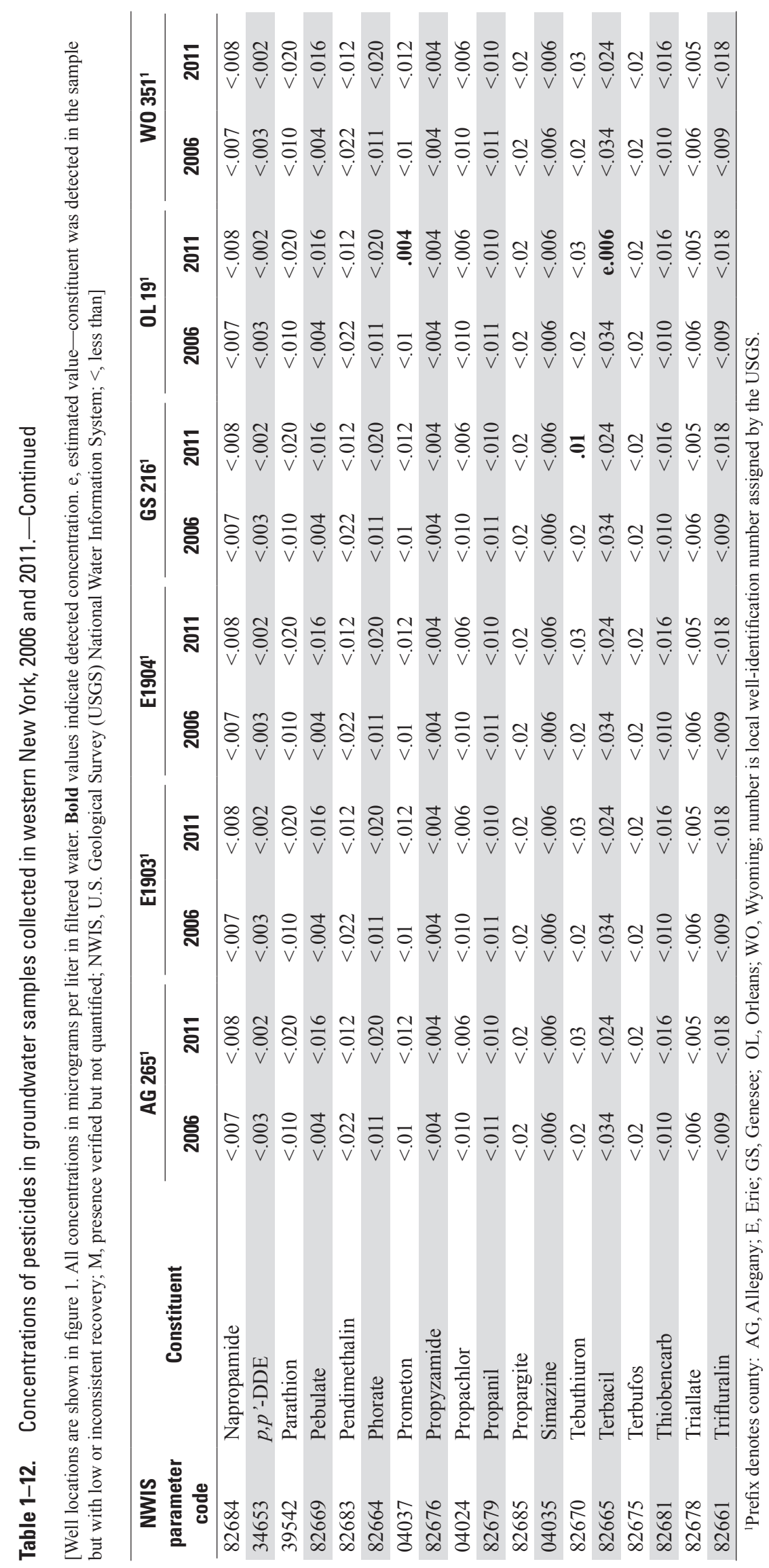


Table 1-13. Concentrations of volatile organic compounds in groundwater samples collected in western New York, 2006 and 2011.

[Well locations are shown in figure 1. All concentrations in micrograms per liter in unfiltered water. Bold values indicate detected concentration. e, estimated value - constituent was detected in the sample but with low or inconsistent recovery; NWIS, U.S. Geological Survey (USGS) National Water Information System; <, less than]

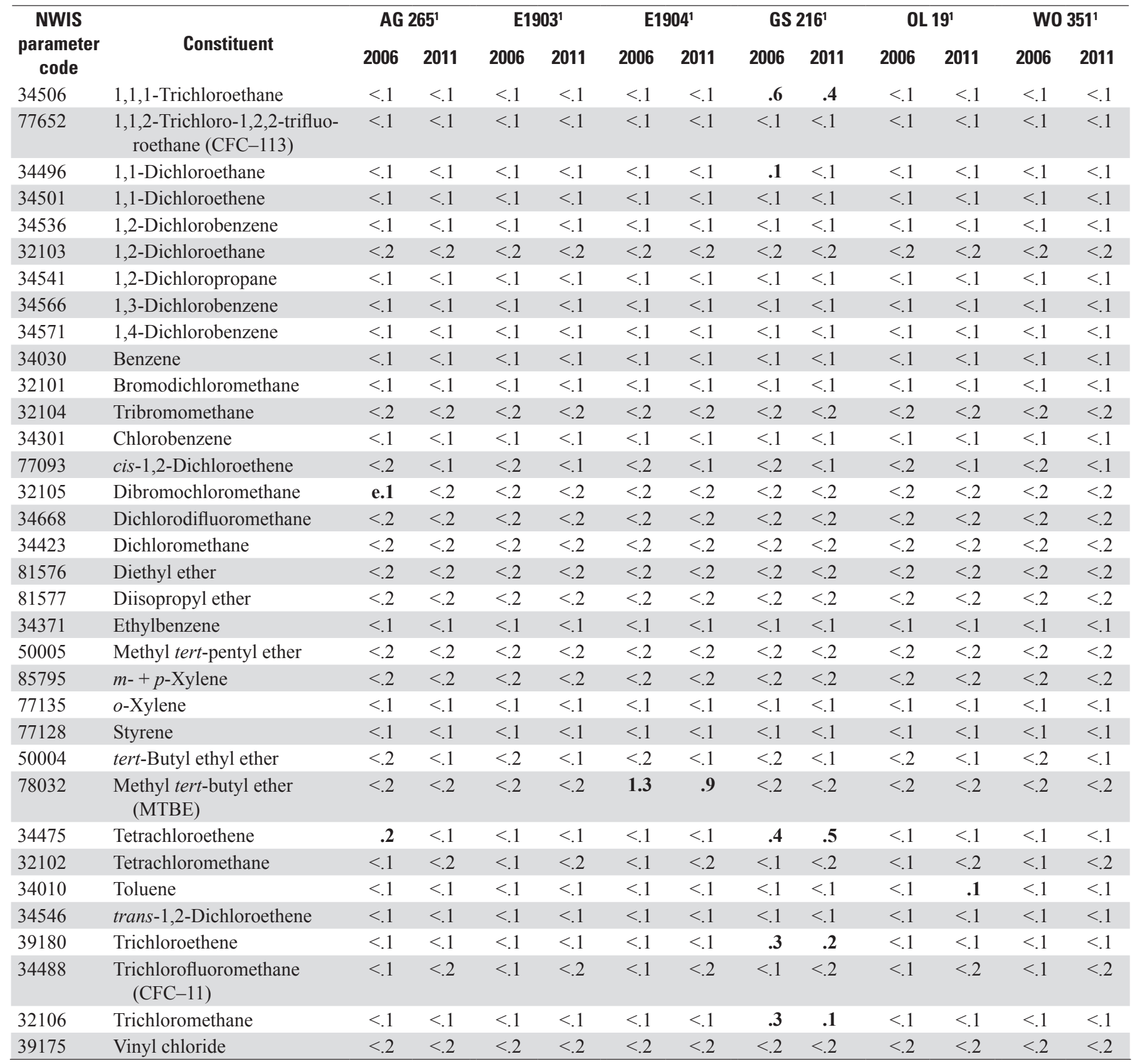

${ }^{1}$ Prefix denotes county: AG, Allegany; E, Erie; GS, Genesee; OL, Orleans; WO, Wyoming; number is local well-identification number assigned bythe USGS. 
Prepared by the Pembroke Publishing Service Center

For additional information write to:

New York Water Science Center

U.S. Geological Survey

30 Brown Rd.

Ithaca, NY 14850

Information requests:

(518) 285-5602

or visit our Web site at: http://ny.water.usgs.gov 


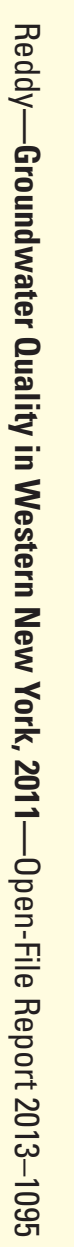

